\title{
Application of In Situ Vitrification in the Soil Subsurface: Engineering-Scale Testing
}

J. Luey

D. K. Seiler

March 1995

Prepared for the U.S. Department of Energy under Contract DE-AC06-76RLO 1830

Pacific Northwest Laboratory Operated for the U.S. Department of Energy by Battelle Memorial Institute 


\title{
DISCLAIMER
}

This report was prepared as an account of work sponsored by an agency of the United States Government. Neither the United States Government nor any agency thereof, nor Battelle Memorial institute, nor any of their employees, makes any warranty, expressed or implied, or assumes any legal liability or responsibility for the accuracy, completeness, or usefulness of any information, apparatus, product, or process disclosed, or represents that its use would not infringe privately owned rights. Reference herein to any specific commercial product; process, or service by trade name, trademark, manufacturer, or otherwise does not necessarily constitute or imply its endorsement, recommendation, or favoring by the United States Government or any agency thereof, or Battelle Memorial Institute. The views and opinions of authors expressed herein do not necessarily state or reflect those of the United States Government or any agency thereof.

\author{
PACIFIC NORTHWEST LABORATORY \\ operated by \\ BATTELLE MEMORIAL INSTITUTE \\ for the \\ UNITED STATES DEPARTMENT OF ENERGY \\ under Contract DE-ACO6-76RLO 1830
}

\author{
Printed in the United States of America \\ Available to DOE and DOE contractors from the \\ Office of Scientific and Technical Information, P.O. Box 62, Oak Ridge, TN 37831; \\ prices available from (615) 576-8401. FTS 626-8401.
}

Available to the public from the National Technical Information Service, U.S. Department of Commerce, 5285 Port Royal Rd., Springfield, VA 22161. 


\section{DISCLA MVER}

Portions of this docoment may be illegible in electronic image prodrets. Impges are produced from the best available origion cocumeot. 
This report was prepared as an account of work sponsored by an agency of the United States Government. Neither the United States Government nor any agency thereof, nor any of their employees, makes any warranty, express or implied, or assumes any legal liability or responsibility for the accuracy, completeness, or usefulness of any information, apparatus, product, or process disclosed, or represents that its use would not infringe privately owned rights. Reference herein to any specific commercial product, process, or service by trade name, trademark, manufacturer, or otherwise does not necessarily constitute or imply its endorsement, recommendation, or favoring by the United States Government or any agency thereof. The views and opinions of authors expressed herein do not necessarily state or reflect those of the United States Government or any agency thereof.

\title{
Application of In Situ Vitrification in the Soil Subsurface: Engineering-Scale Testing
}

\author{
J. Luey \\ D. K. Seiler
}

March 1995

Prepared for

the U.S. Department of Energy

under Contract DE-AC06-76RLO 1830

\author{
Pacific Northwest Laboratory \\ Richland, Washington 99352
}


Engineering-scale testing to evaluate the initiation and propagation of the in situ vitrification (ISV) process in the soil subsurface has been completed. Application of ISV in the soil subsurface both increases the applicable treatment depth (beyond a demonstrated $5 \mathrm{~m}$ ) and allows treatment of local contamination, such as liquid seepage trenches (found on many U.S. Department of Energy sites) that were designed to remove contamination at the bottom of the trench.

The following observations and conclusions resulted from the test data:

- The ISV process can be initiated in the soil subsurface and propagated in both vertical directions, with the downward direction providing greater ease of operation.

- Energy efficiency to process a kilogram of soil was $20 \%$ better than for an ISV melt initiated at the soil surface. Increased efficiency was attributed to insulation from the soil overburden.

- The feasibility of initiating the process with a planar starter path was confirmed, thus increasing the number of options for initiating the process in the field.

- Soil subsidence was pronounced and requires attention before field demonstration of subsurface ISV.

Further field work at pilot-scale is recommended for this new ISV application. The key step will be the placement of starter material at depth to initiate the process. 



\section{ACKNOWLEDGMENTS}

Pacific Northwest Laboratory (PNL) gratefully acknowledges the U.S. Department of Energy Office of Environmental Restoration, Richland Operations Office, for providing the funding to perform this engineering-scale test. This engineering-scale test was performed in support of the ISV Spot Melting project managed by PNL. Programmatic guidance for the project was provided by the Westinghouse Hanford Company and by Bechtel Hanford Incorporated.

The authors also wish to acknowledge the efforts of the following PNL staff members who participated in the engineering-scale test and ensured its success: PS Lowery, TD Powell, WA Sliger, and JS Tixier. 

CONTENTS

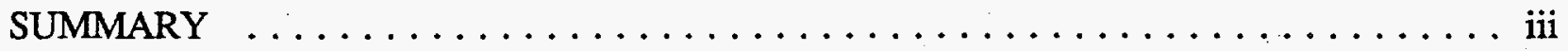

ACKNOWLEDGMENTS $\ldots \ldots \ldots \ldots \ldots \ldots \ldots \ldots \ldots \ldots \ldots \ldots \ldots \ldots \ldots \ldots$

1.0 INTRODUCTION AND OBJECTIVES $\ldots \ldots \ldots \ldots \ldots \ldots \ldots \ldots \ldots \ldots$

2.0 CONCLUSIONS AND RECOMMENDATIONS $\ldots \ldots \ldots \ldots \ldots \ldots \ldots \ldots$

3.0 TEST CONFIGURATION $\ldots \ldots \ldots \ldots \ldots \ldots \ldots \ldots \ldots \ldots \ldots \ldots \ldots$

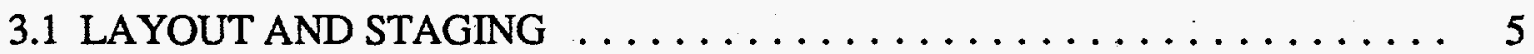

3.2 INSTRUMENTATION $\ldots \ldots \ldots \ldots \ldots \ldots \ldots \ldots \ldots \ldots \ldots$

3.3 DATA ACQUISITION SYSTEM $\ldots \ldots \ldots \ldots \ldots \ldots \ldots \ldots \ldots \ldots$

4.0 RESULTS AND DISCUSSION $\ldots \ldots \ldots \ldots \ldots \ldots \ldots \ldots \ldots \ldots \ldots \ldots$

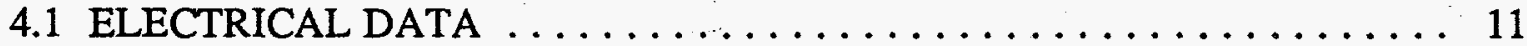

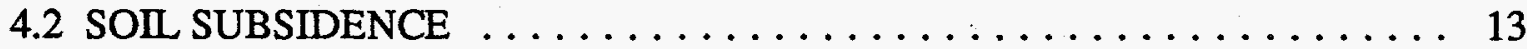

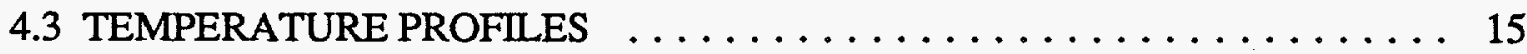

4.4 PREDICTED MELT SHAPE $\ldots \ldots \ldots \ldots \ldots \ldots \ldots \ldots \ldots \ldots \ldots \ldots$

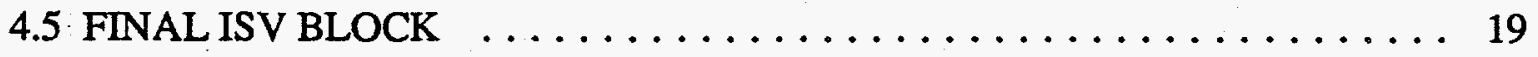

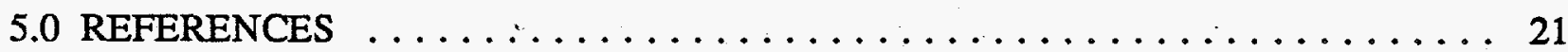


FIGURES

3.1 Engineering-Scale Test Configuration (instrument locations not shown) $\ldots \ldots \ldots 6$

3.2 Starter Path Configuration Relative to Electrode Casings and Vent $\ldots \ldots \ldots$

3.3 Location of Thermocouple Arrays for Engineering-Scale Test $\ldots \ldots \ldots \ldots$

4.1 Power Input and Energy Consumption Curves $\ldots \ldots \ldots \ldots \ldots \ldots \ldots$

4.2 Voltage and Current Profiles for the B-Phase Electrode $\ldots \ldots \ldots \ldots \ldots \ldots$

4.3 Average Electrical Resistance for the B-Phase Electrode $\ldots \ldots \ldots \ldots \ldots$

4.4 Electrode and Casing Before Soil Subsidence $\ldots \ldots \ldots \ldots \ldots \ldots$

4.5 Subsidence at Hour 4.75 - B-Casing, C-Casing, and Vent . . . . . . . . 15

4.6 Observation of Subsidence at End of Engineering-Scale Test $\ldots \ldots \ldots \ldots$

4.7 Temperature Profile of Vertical Thermocouple Array Below Vitrification Zone $\ldots \ldots$

4.8 Temperature Profile of Vertical Thermocouple Array Above Vitrification Zone $\ldots \ldots$. 17

4.9 Temperature Profile of Lateral Thermocouple Array $\ldots \ldots \ldots \ldots \ldots$

4.10 Melt Depth for Engineering-Scale Test $\ldots \ldots \ldots \ldots \ldots \ldots$

4.11 Final Engineering-Scale Block with B-Electrode Phase Exposed . . . . . . . . . 20

\section{TABLES}

3.1 Measured Electrical Resistance Between Electrode Pairs $\ldots \ldots \ldots \ldots \ldots$

4.1 Test Operator Observations of Soil Subsidence During Engineering-Scale Test . . . . . 14 


\subsection{INTRODUCTION AND OBJECTIVES}

The in situ vitrification (ISV) process has been demonstrated at depths up to $5.8 \mathrm{~m}$ in relatively homogeneous soils (Buelt and Thompson 1992). The achievable depth, however, can be limited under certain conditions, such as limited efficiency of heat transfer in the presence of a rock or gravel layer or a soil layer with significantly higher melting temperature than the overlying material. Depths of $4.3 \mathrm{~m}$ and $5.2 \mathrm{~m}$ have been achieved when rock layers existed at those depths (Luey et al. 1992). In addition, the density of the soils influences both the achievable melt depth and the operating efficiency (processing of higher-density soils requires more time and energy).

In March 1994, the Pacific Northwest Laboratory (PNL)(a) conducted an engineering-scale ISV test to investigate the initiation and propagation of the ISV process in the soil subsurface. This work builds on previous proof-of-principle testing performed in 1992 (an overview of the benchscale test is presented in Appendix A) and on research evaluating the application of ISV for subsurface barriers (Tixier, Stottlemyre, and Murphy 1991). The 1994 test used a 3-electrode configuration and a planar conductive region as a starter path. In addition, a central vent pipe and simulated "casings" for the electrodes were used to mimic a postulated field-scale scenario. The three main objectives for the tests were as follows:

1. Determine the feasibility of initiating the ISV process at depth and propagating downward. Proof-of-principle testing investigated upward propagation of the melt. Models of the ISV process show the upper region of a melt to be the hottest. Therefore, heat transfer from the melt to the surrounding soil makes upward propagation more likely than downward. Determining the potential for downward growth is necessary for a complete design of field applications.

2. Evaluate the effects (electrical, thermal, melt shape, and melt rate) of soil subsidence on a subsurface, downward-propagating ISV melt. During the proof-of-principle test, soil subsidence was visible from the surface and may have been responsible for erratic current and voltage levels realized during the test.

3. Verify the ability to start the ISV process with a planar conductive region as a starter path and determine the effect of soil overburden. A planar starter path is a suitable alternative to the reference starter path (Luey and Seiler 1994). However, these previous tests were initiated at shallow depths of $\approx 5 \mathrm{~cm}$. Successfully using the planar path at greater depths will increase the field options available for initiating the ISV process.

(a) Pacific Northwest Laboratory is operated by Battelle Memorial Institute for the U.S. Department of Energy 



\subsection{CONCLUSIONS AND RECOMMENDATIONS}

The engineering-scale test investigating the initiation and propagation of the ISV process in the soil subsurface was completed in March 1994. Analysis and evaluation of the data provided the following conclusions:

- The ISV process can be initiated in the soil subsurface and propagated downward. Initially, the melt grows in both vertical directions with a slight upward preference. However, this trend is reversed as the melt becomes larger. The formation of a void space above the molten soil pool that changes the heat transfer mechanism from conduction to radiation is postulated as causing this trend reversal. The position of the electrodes is not a major contributing factor because they remain at the bottom of the molten soil pool.

- The 1994 test current and voltage profiles were smooth and not affected by soil subsidence. Temperature profiles beneath the vitrification zone were similar to those of ISV tests initiated from the surface; the profiles from the thermocouples above the vitrification zone reflected the effects of soil subsidence (i.e., cooling as soil subsides into warmer regions).

- The melt rate and final melt shape were typical for this ISV scale. However, one notable difference between the 1994 test and typical engineering-scale tests (initiated at the surface) was the ratio of energy consumed to mass of soil vitrified. In the 1994 test, the ratio was $0.8 \mathrm{kWh} / \mathrm{kg}$, versus a typical ratio of 1.0 . This increased efficiency is attributed to the minimization of heat-transfer losses to the air-space above the melt.

- The planar starter path was an effective means of initiating the ISV process. The path became more electrically conductive as soil overburden increased. This is attributed to the increased pressure of the overburden, causing increased contact between particles in the starter path. However, the increase in conductivity was not sufficient to cause a problem during start up of the ISV process.

- $\quad$ Pronounced subsidence of the sandy soils tested may be a problem in field applications. An analysis of the potential for soil subsidence for soils typical of the Hanford Site (predominately glacial till consisting of cobbles and coarse grained sand) should precede a field demonstration of this new ISV application. Such an analysis should also be performed for other soil types (e.g., clays, fine grained silts).

The engineering-scale test demonstrated the feasibility of initiating and downward propagation of the ISV process in the soil subsurface. Test results support continued development of this application for a field demonstration at the Hanford Site. In addition to providing a direct means for increasing the applicable depth of the ISV technology, this new application may also increase the efficiency with which energy is used. Technical issues associated with soil subsidence 
should be addressed as part of preparation activities for a field demonstration and should include 1) an analysis of the potential for soil subsidence, 2) an evaluation of the impact soil subsidence would have on the ISV equipment and process, and 3) the design of engineered systems to mitigate the effects of soil subsidence (e.g., shoring for the off-gas hood, supports for the electrode casings or vent pipes). Aside from technical issues associated with soil subsidence, the key step for field demonstration of this new ISV application will be the placement of a conductive region inside an electrode array at a target depth. 


\subsection{TEST CONFIGURATION}

The engineering-scale test investigating the initiation and propagation of the ISV process in the soil subsurface was performed at PNL's engineering-scale ISV unit (for a complete description of the unit, see Luey et al. 1992). The test was done on nonhazardous and nonradioactive Hanford soil. Soil used was predominately fine to medium-grained sand, rather than the cobble and coarsegrained sand that are more typical of Hanford. Use of sand for testing at this scale facilitates staging of the test configuration and post-test removal of the product. A standard mixture of graphite and glass frit was used for starter material.

\subsection{LAYOUT AND STAGING}

Figure 3.1 shows the plan and elevation views for the position of electrodes, electrode casings, starter material, and central vent pipe (instrumentation layout is described in Section 3.2). A 3-electrode array was used with 56-cm spacing between each electrode (centerpoint of each electrode is on a circle of radius $32.3 \mathrm{~cm}$ ). Choice of a 3-electrode array was based on operational experience with planar starter paths (Luey and Seiler 1994).

The electrical resistance of the planar starter path was predicted to be low ( $<10 \mathrm{ohms})$ such that the $75 \mathrm{kVA}$ transformer could be used during start up. This electrical configuration allows continuous operation without the need for electrical tap changes (which would be the case with the engineering-scale system's Scott-connected transformer and a 4-electrode array). At worst, the electrical resistance of the starter path would exceed $10 \mathrm{ohms}$ and require bypass of the $75 \mathrm{kVA}$ transformer (which would provide up to 480 volts). This configuration would result in a single downtime when the voltage and current requirements allowed the $75 \mathrm{kVA}$ transformer to be put into service.

The vent pipe and electrode casings shown in Figure 3.1 were $15.2-\mathrm{cm}$ diameter sections of stove pipe. Figure 3.1 shows the final position of the casings relative to the starter path. The following procedure was followed for the placement of electrode casings, central vent, starter material, and electrodes (instrument placement, discussed in Section 3.2, was performed in parallel).

- The engineering-scale unit was backfilled to a depth of $62 \mathrm{~cm}$ from zero grade. Each of the electrode casings was driven such that its bottoms was at a depth of $65 \mathrm{~cm}$. The bottom of the central vent was at $62 \mathrm{~cm}$. 
Plan

View

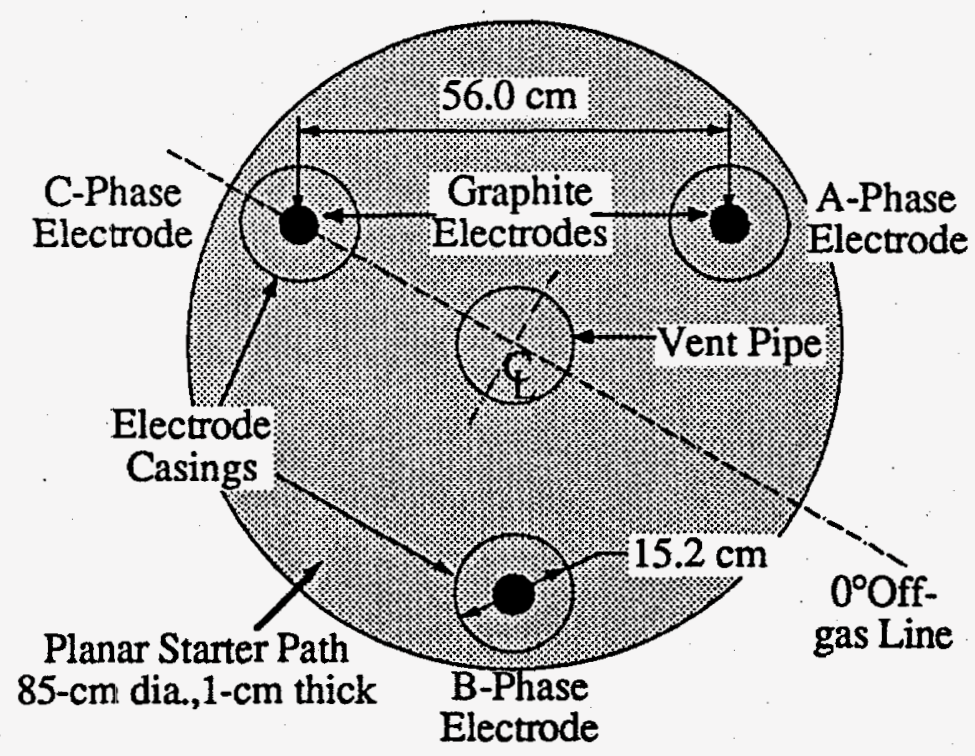

\section{Elevation}

View

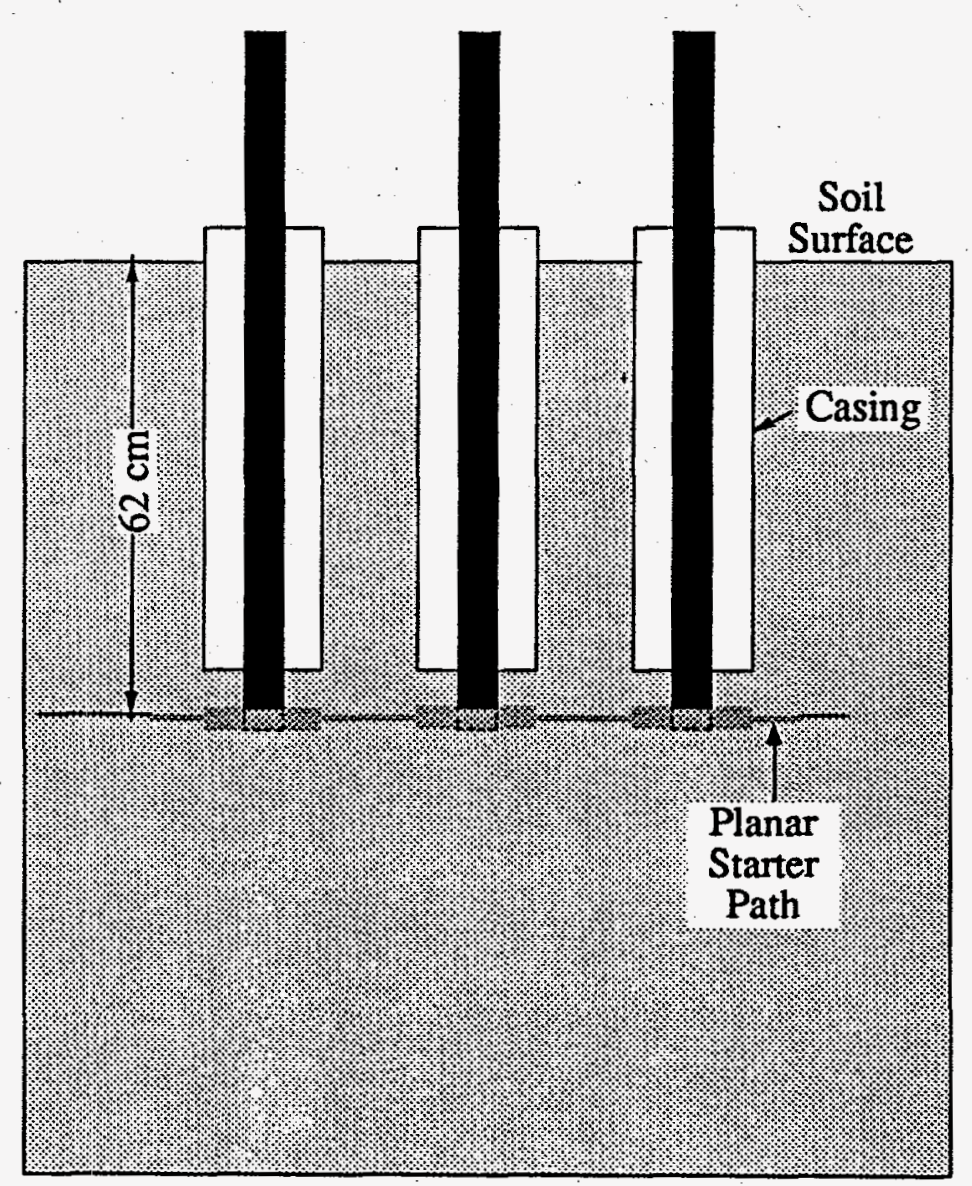

FIGURE 3.1. Engineering-Scale Test Configuration (instrument locations not shown) 
- A 1-cm thick, $85-\mathrm{cm}$ diameter layer of starter material was placed to encompass the casings and central vent (see Figure 3.2). The addition of $8 \mathrm{~cm}$ of soil brought the depth of the soil to $54 \mathrm{~cm}$ from zero grade.

- The lid to the engineering-scale unit was attached, and the electrodes were lowered to the bottom of the casings. Starter material was added to each annular space between the electrode and the electrode casing such that the level was between 3 and $5 \mathrm{~cm}$. This added starter material provided the means to electrically connect an electrode to the planar starter path after the casings were retracted above the 62-cm depth.

- Each electrode casing was retracted to $55 \mathrm{~cm}$ to establish a path between each electrode and the planar starter material at the 62-cm depth. Electrical measurements were then taken using the procedure outlined in Luey and Seiler (1994) to ensure completion of the electrical circuit. Table 3.1 lists the results from the measurement taken both before and after the engineering unit was backfilled with soil to zero grade.

- Once it was determined that a conductive path existed between each pair of electrodes, the engineering unit was backfilled with soil to zero grade.

This procedure was developed from the assumption that in a field-scale application the ISV starter material would be pre-placed at a target depth. Regardless of the specific method used for placement, the success of this ISV application requires electrical contact between the electrodes and

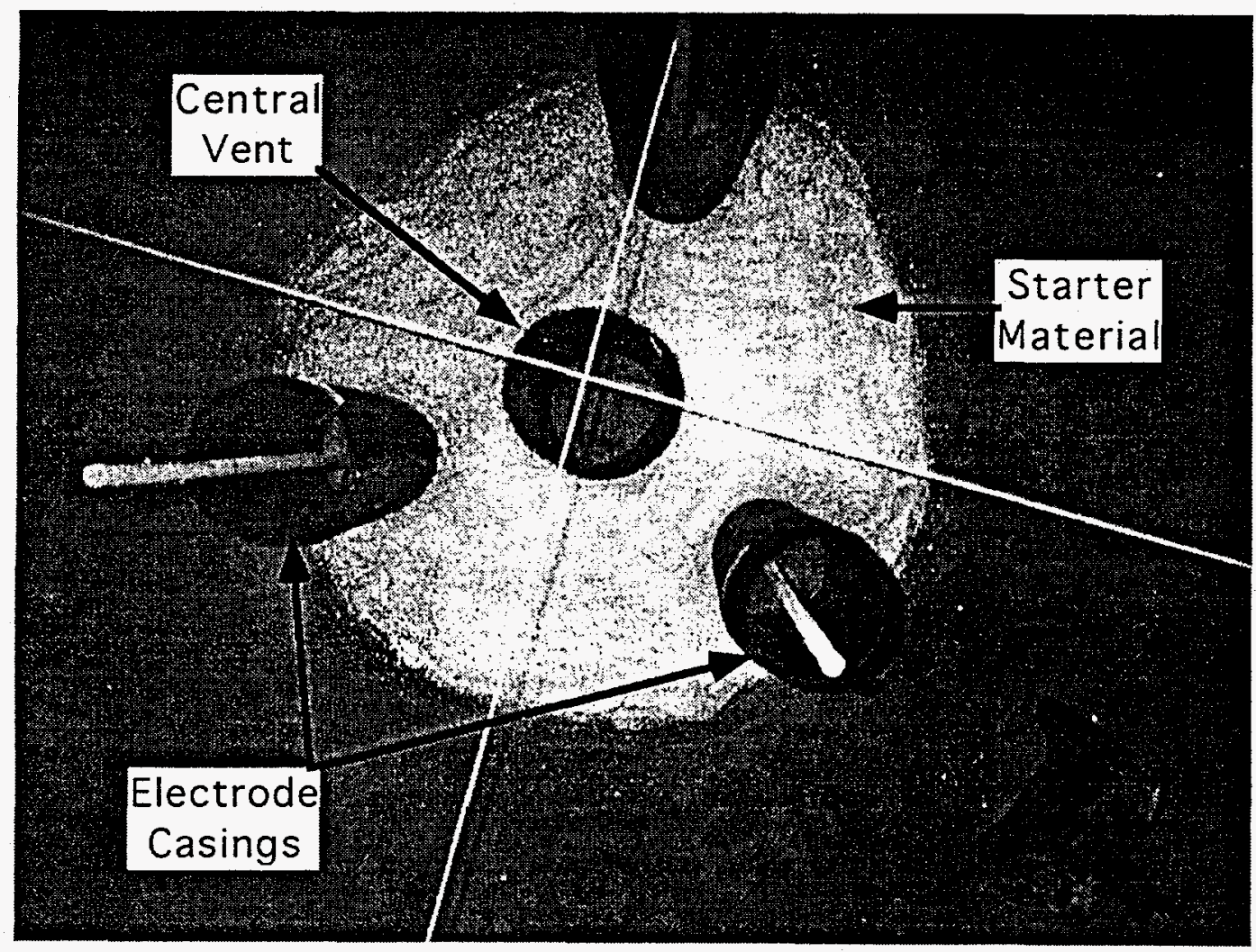

FIGURE 3.2. Starter Path Configuration Relative to Electrode Casings and Vent 
TABLE 3.1. Measured Electrical Resistance Between Electrode Pairs

Soil Overburden Height. $8 \mathrm{~cm}$

$\begin{array}{llll}\text { Electrode Pair } & \text { Voltage, volts } & \text { Current. amps } & \begin{array}{c}\text { Calculated } \\ \text { Resistance. ohms }\end{array} \\ \text { A-B } & 10.3 & 1.56 & 6.6 \\ & 19.6 & 3.2 & 6.1 \\ \text { B-C } & 29.7 & 5.2 & 5.7 \\ & 9.5 & 1.7 & 5.6 \\ & 19.3 & 5.7 & 5.2 \\ \text { A-C } & 27.5 & 2.0 & 5.0 \\ & 10.7 & 3.7 & 5.4 \\ & 19.0 & 5.6 & 5.1 \\ & 27.4 & & 4.9 \\ & & & \\ \text { Electrode Pair } & & \text { Soil Overburden Height. } 61 \mathrm{~cm} & \\ \text { A-B } & & & \text { Calculated } \\ & \text { Voltage, volts } & \text { Current. amps } & \text { Resistance. ohms } \\ \text { B-C } & 9.6 & 3.4 & 2.8 \\ & 17.4 & 6.8 & 2.5 \\ \text { A-C } & 9.15 & 2.8 & 3.3 \\ & 18.7 & 6.2 & 3.0 \\ & 10.0 & 4.2 & 2.4 \\ & 17.0 & 7.6 & 2.2\end{array}$

the starter material. To obtain this in the field, vertical boreholes would be drilled to intersect the starter material. Casings would be used to hold the borehole open and allow free vertical travel of the electrode. Material added to the annular space would provide electrical contact between the electrodes and starter path after the casings have been retracted out of the path.

\subsection{INSTRUMENTATION}

Figure 3.3 illustrates the location of the three Type- $\mathrm{K}$ thermocouple arrays (upper, lower, and lateral) for the engineering-scale test. The upper array consisted of 5 thermocouples located between $0-\mathrm{cm}$ and $60-\mathrm{cm}$ depth and spaced $15-\mathrm{cm}$ apart. Because of the vent pipe, the array was 
Plan

View

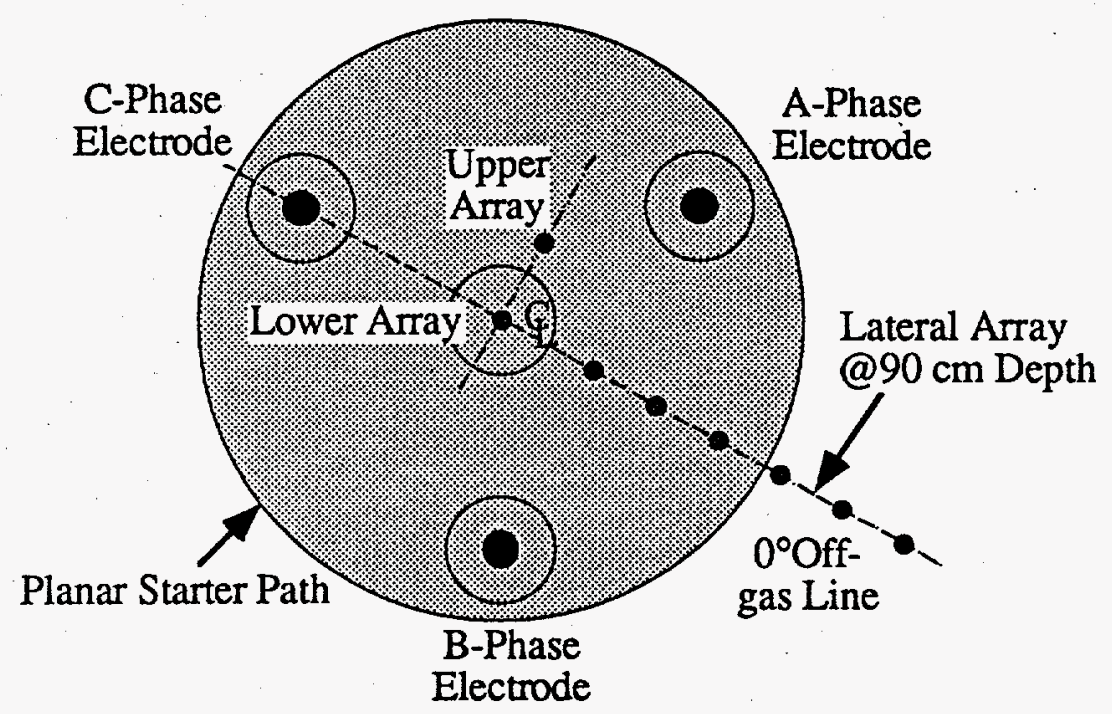

- Indicates Thermocouple

\section{Elevation \\ View}

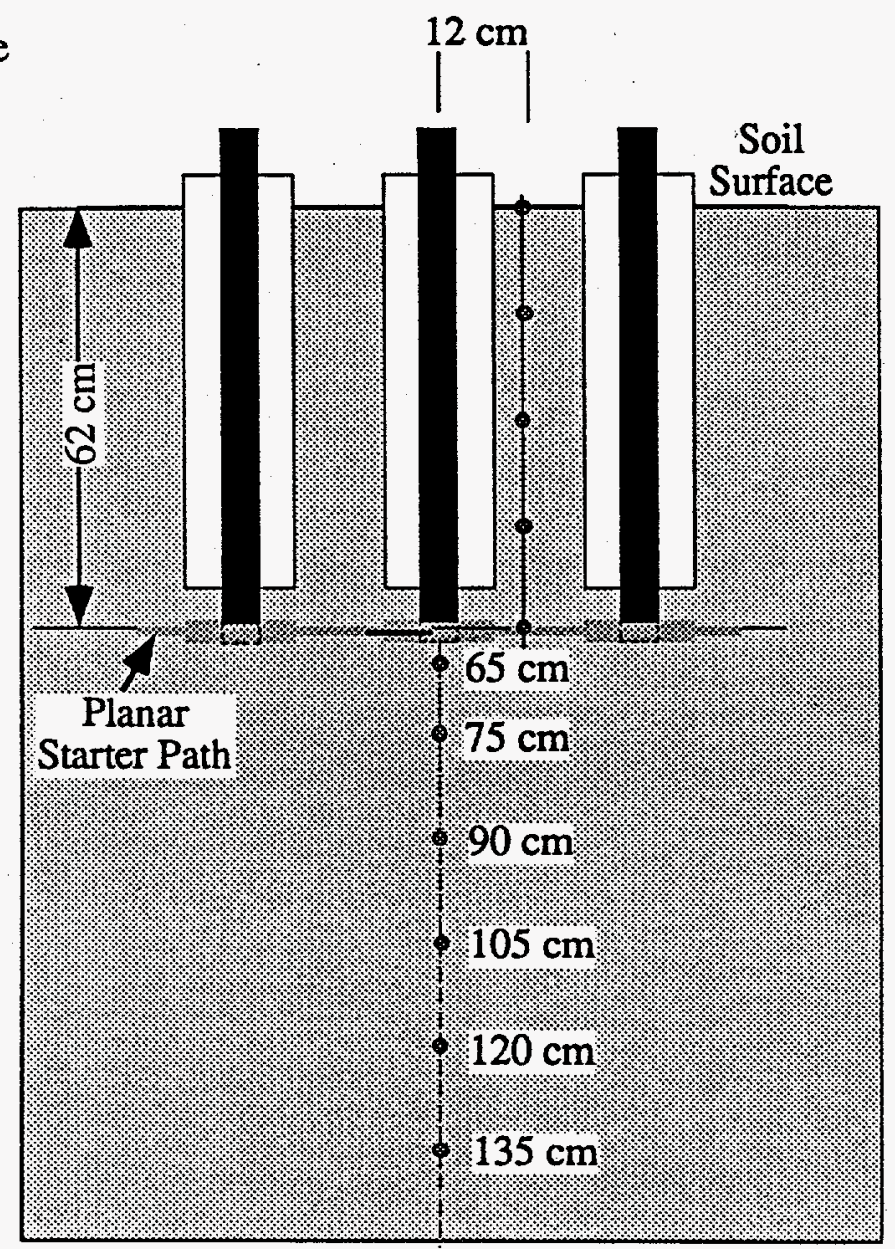

FIGURE 3.3. Location of Thermocouple Arrays for Engineering-Scale Test 
$12 \mathrm{~cm}$ off center. The upper array was supported by a tripod assembly so that soil subsidence would not change the position of the thermocouples relative to zero grade.

Temperatures below the planar starter path were measured by 6 thermocouples spaced $15 \mathrm{~cm}$ apart (except for a 10-cm space between thermocouples at depths of 65 and $75 \mathrm{~cm}$ ) between the $65-\mathrm{cm}$ and $135-\mathrm{cm}$ depths. A lateral array was placed at a depth of $90 \mathrm{~cm}$. This bundle monitored temperatures at radial increments of $10 \mathrm{~cm}$ from a radius of $15-\mathrm{cm}$ to $65-\mathrm{cm}$ from the vertical centerline. This bundle provided an indication of the outward growth of the melt.

\subsection{DATA ACQUISITION SYSTEM}

The data acquisition system (DAS) hardware and software used for the collection of thermocouple and power-related data was similar to that used for previous ISV tests (see Luey et al. 1992 and Luey and Seiler 1994). A Macintosh $\circledast$ computer running LabView® software recorded thermocouple data every 30 seconds; an IBM PC running a PNL-written program displayed current and voltage data every 6 seconds and recorded the data every 30 seconds. 


\subsection{RESULTS AND DISCUSSION}

The 1994 engineering-scale test was operated for 22.8 hours with a total downtime of 6 minutes. Total energy consumed, to create a final block weighing $840 \mathrm{~kg}$, was $650 \mathrm{kWh}$, for an energy to mass ratio of $0.8 \mathrm{kWh} / \mathrm{kg}$, or $20 \%$ lower than that typical $(1.0 \mathrm{kWh} / \mathrm{kg})$ for this test scale. Insulation from the soil overburden (which is not present in a conventional ISV melt initiated at the soil surface) reduced the heat loss to the off-gas plenum, thus increasing energy efficiency. Test operator notations described smooth power operation with no discernible effects from soil subsidence. The remaining subsections discuss electrical data, soil subsidence, temperature profiles, and the final ISV block.

\subsection{ELECTRICAL DATA}

Figure 4.1 illustrates the power-input and energy-consumption curves. Pre-test measurements (see Table 3.1) showed an average resistance of $2.7 \mathrm{ohms}$ between the electrodes. Since this was below $10 \mathrm{ohms}$, the $75 \mathrm{kVA}$ transformer was used for both start-up and steady-state operation. A start-up schedule of $1 \mathrm{~kW}$ every $6 \mathrm{~min}$ was followed until the target steady-state

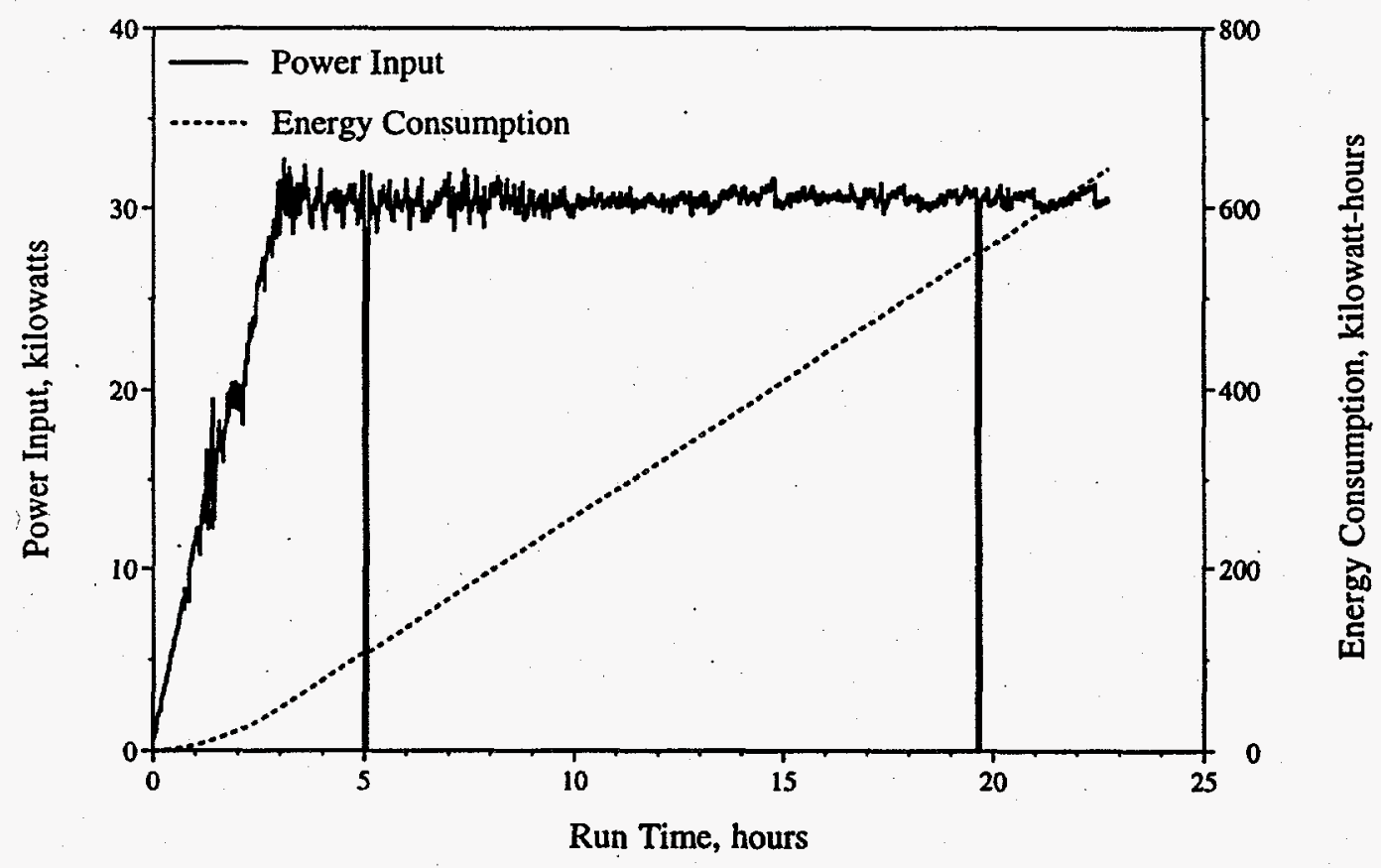

FIGURE 4.1. Power Input and Energy Consumption Curves 
power level, $30 \mathrm{~kW}$, was reached at hour 3 . Approximately $650 \mathrm{kWh}$ were consumed during the 22.8-hour test. The system was powered down for $4 \mathrm{~min}$ at hour 5 to add sections of electrodes and for $2 \mathrm{~min}$ at hour 19.8 to repair a broken electrode joint.

Figure 4.2 illustrates the voltage and current profiles for the B-phase electrode (similar profiles for the A-phase and C-phase electrodes suggest electrical balance during processing). Figure 4.3 illustrates the average electrical resistance of the three phases. As shown, resistance was approximately $1 \mathrm{ohm}$, or less, so that the required voltage input during start-up did not approach the transformer's $207 \mathrm{VAC}$ limit. This confirms observations in previous tests involving a planar starter path (Luey and Seiler 1994) and shows that $60 \mathrm{~cm}$ of soil overburden has no significant effect on the starter path performance. The smooth curves during steady-state operation (after hour 5) reflect the ease of operation noted by the test operators. Soil subsidence had no apparent effect on the electrical performance of the ISV test.

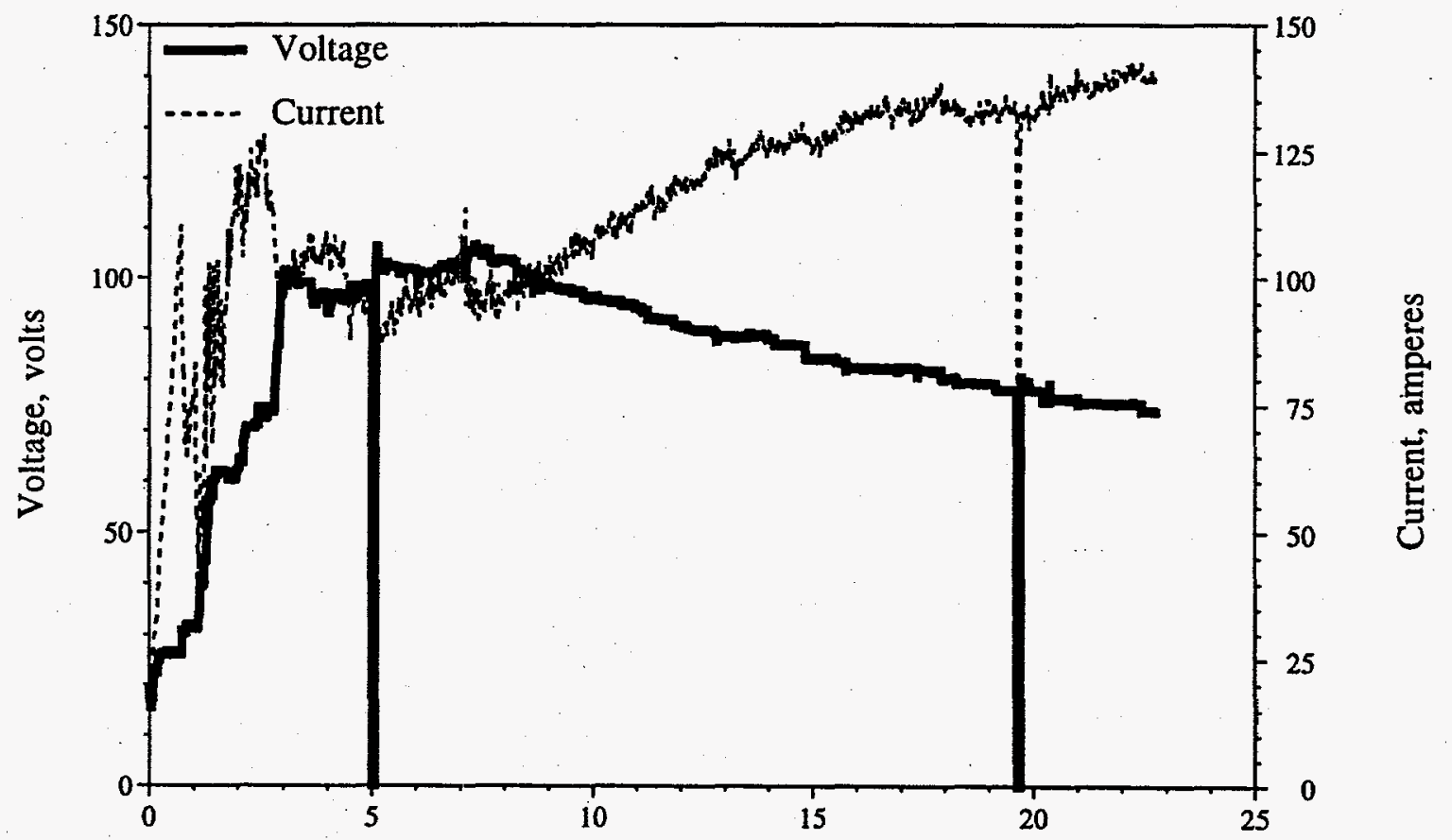

Run Time, hours

FIGURE 4.2. Voltage and Current Profiles for the B-Phase Electrode 


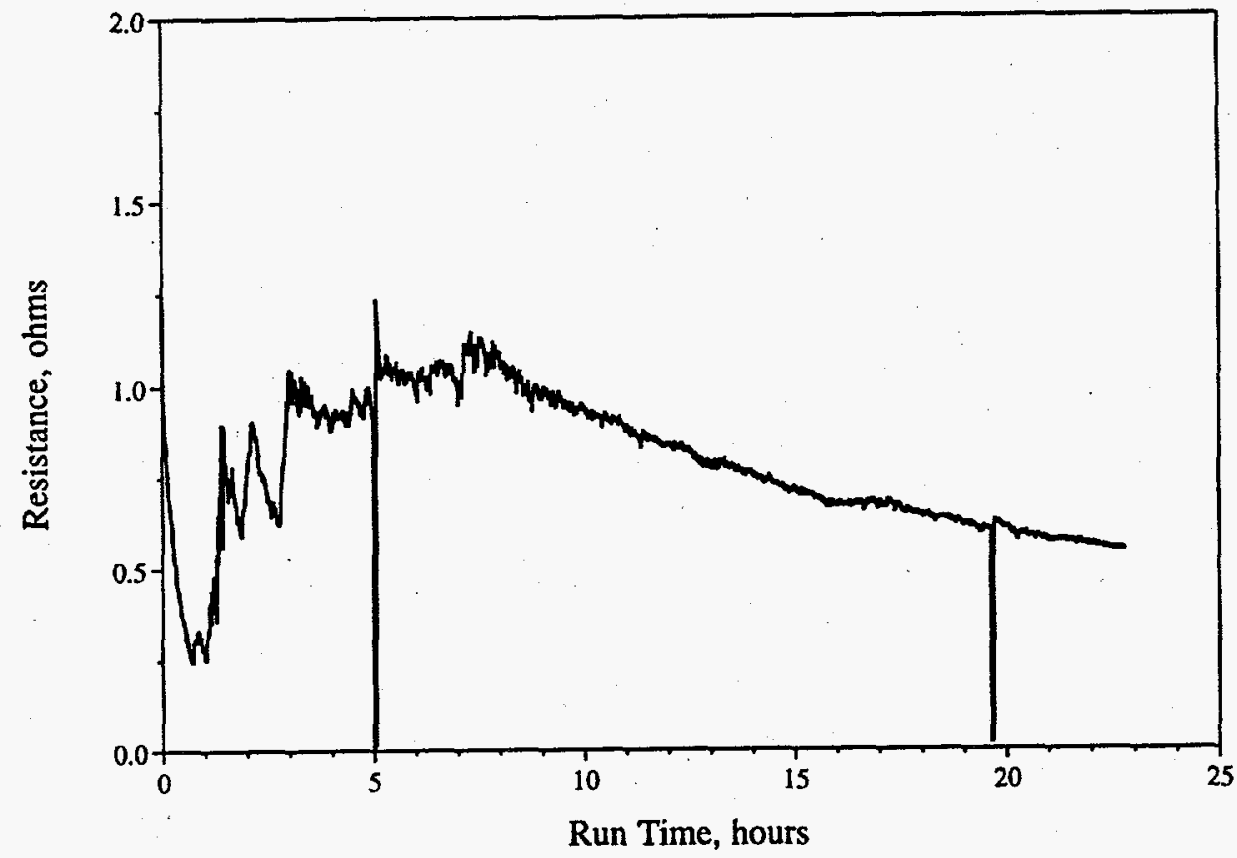

FIGURE 4.3. Average Electrical Resistance for the B-Phase Electrode

\subsection{SOIL SUBSIDENCE}

Table 4.1 summarizes observations made by test operators during the engineering-scale test. As indicated in this table, subsidence was not uniform in the region between the electrode casings nor was it a continuous event. When subsidence did occur, it was located next to an electrode casing or the vent. These locations may represent "weak" points, due to the penetration of the casing (or vent), in the soil matrix or in the sintered soil above the melt. Since dry sand flows very easily, it has been postulated that penetration into the weak points in the sintered zone allows soil to fill whatever void exists above the melt. If the mechanism is a weak point in the soil matrix, the nature of the soil supports the conclusion that subsidence would be more continuous than sudden.

Figures 4.4 through 4.6 show, respectively, the position of a casing relative to surface grade before the test, at hour 4.75 (with subsidence extending from the B-electrode casing (B-casing) to the vent), and at test completion (when the vent pipe had been engulfed by the soil and was not visible). Average subsidence was estimated to be $17 \mathrm{~cm} ; 33 \mathrm{~cm}$ was the maximum subsidence depth measured. 
TABLE 4.1. Test Operator Observations of Soil Subsidence During Engineering-Scale Test

Run Time, hours

3.75

4.38

4.75

5.76

7.50

11.63

13.00

14.75

16.66

19.71

20.28

22.80
Observation

No evidence of soil subsidence.

Subsidence of $\approx 16 \mathrm{~cm}$ around $\mathrm{B}$-casing and $6 \mathrm{~cm}$ around C-casing. None visible around A-casing or vent pipe. All casings and vent appear in original position. Thermocouples indicate preferred melt growth is upward.

Subsidence around B-casing extends to vent pipe. Casing appears to be sinking with soil subsidence.

Both B- and C-casing appear to have fallen approximately $4 \mathrm{~cm}$.

Pronounced subsidence around $\mathrm{B}$-casing and none around $\mathrm{A}$-casing.

Soil around A-casing has significantly subsided. Entire region between the electrode casings shows evidence of subsidence. B- and C-casings only ones that appear to have fallen.

Vent has shifted toward B-casing.

A- and B-casings appear to be leaning against electrodes.

All casings leaning against respective electrodes.

Average subsidence in region between electrode casings is $\approx 16.5 \mathrm{~cm}$.

Vent has subsided to the point where it is barely visible at the surface.

Thermocouple at $120-\mathrm{cm}$ depth reached $1200^{\circ} \mathrm{C}$, power terminated.

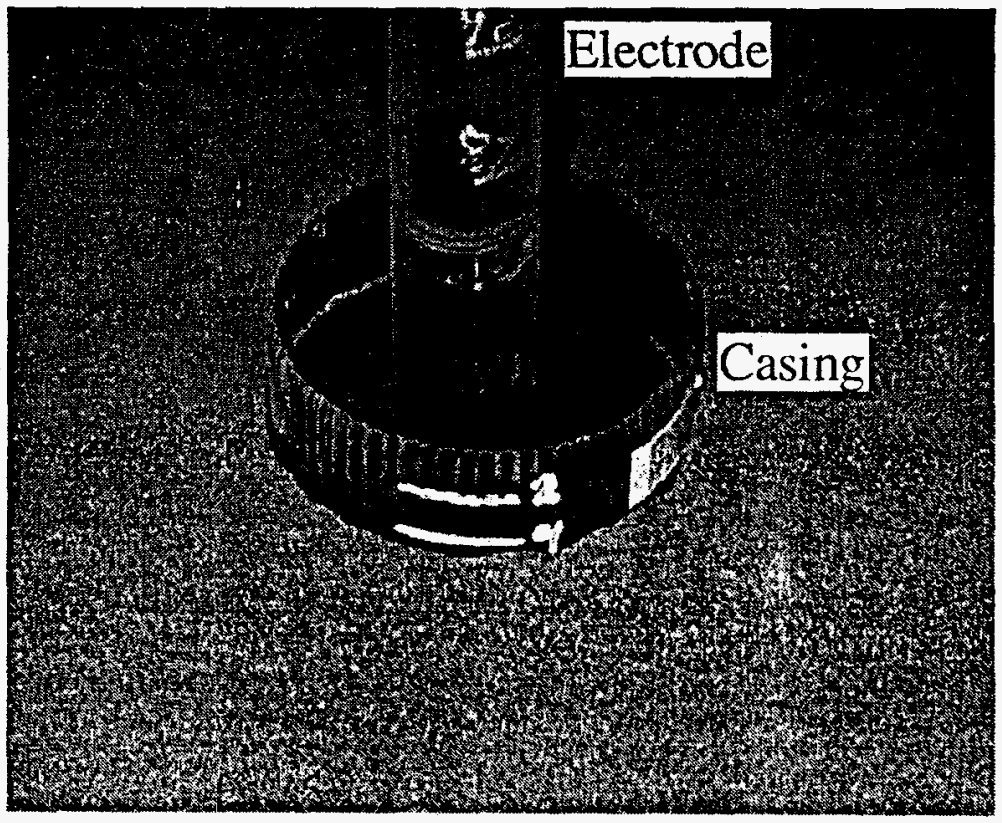

FIGURE 4.4. Electrode and Casing Before Soil Subsidence 


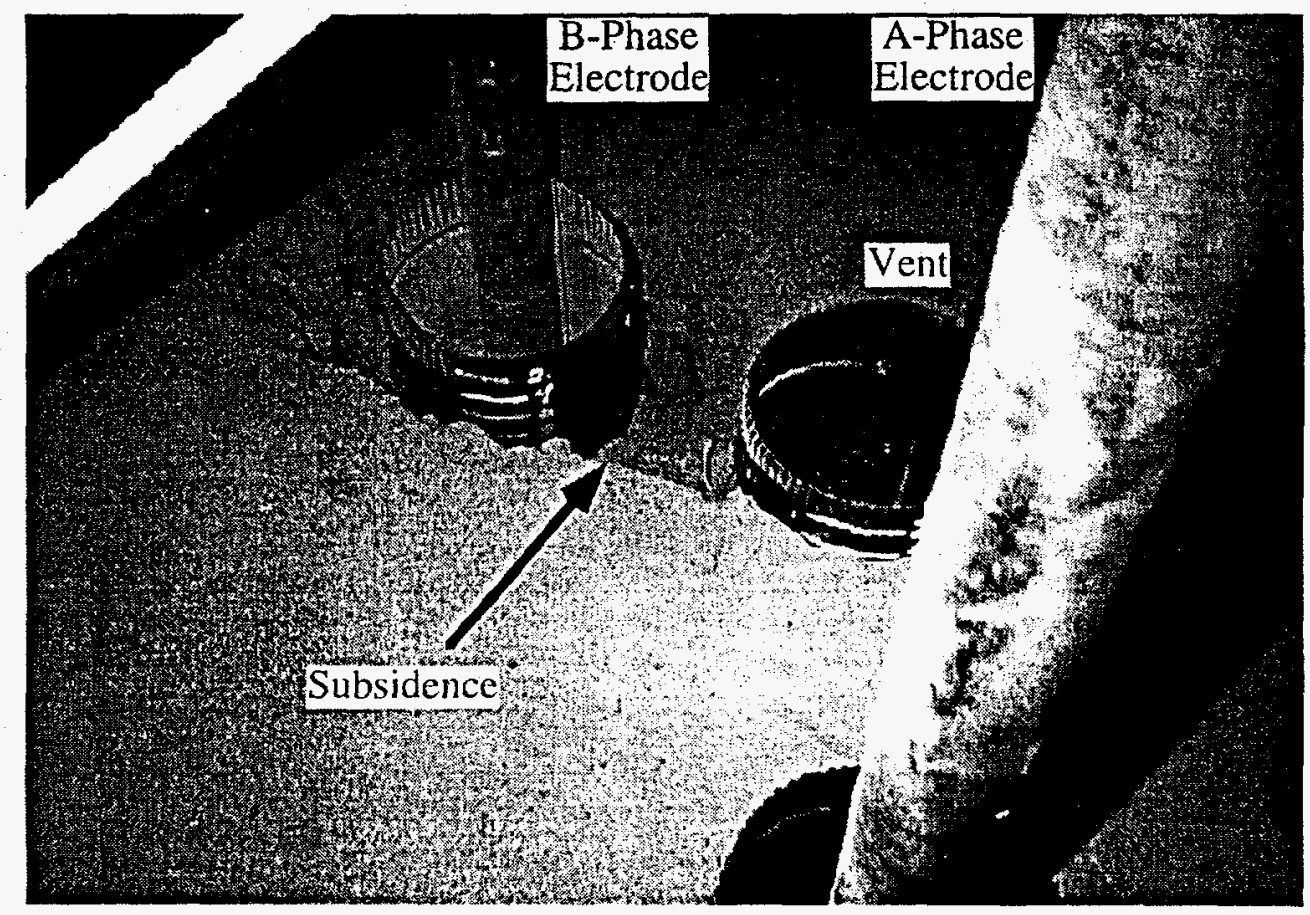

FIGURE 4.5. Subsidence at Hour 4.75 - B-Casing, C-Casing, and Vent

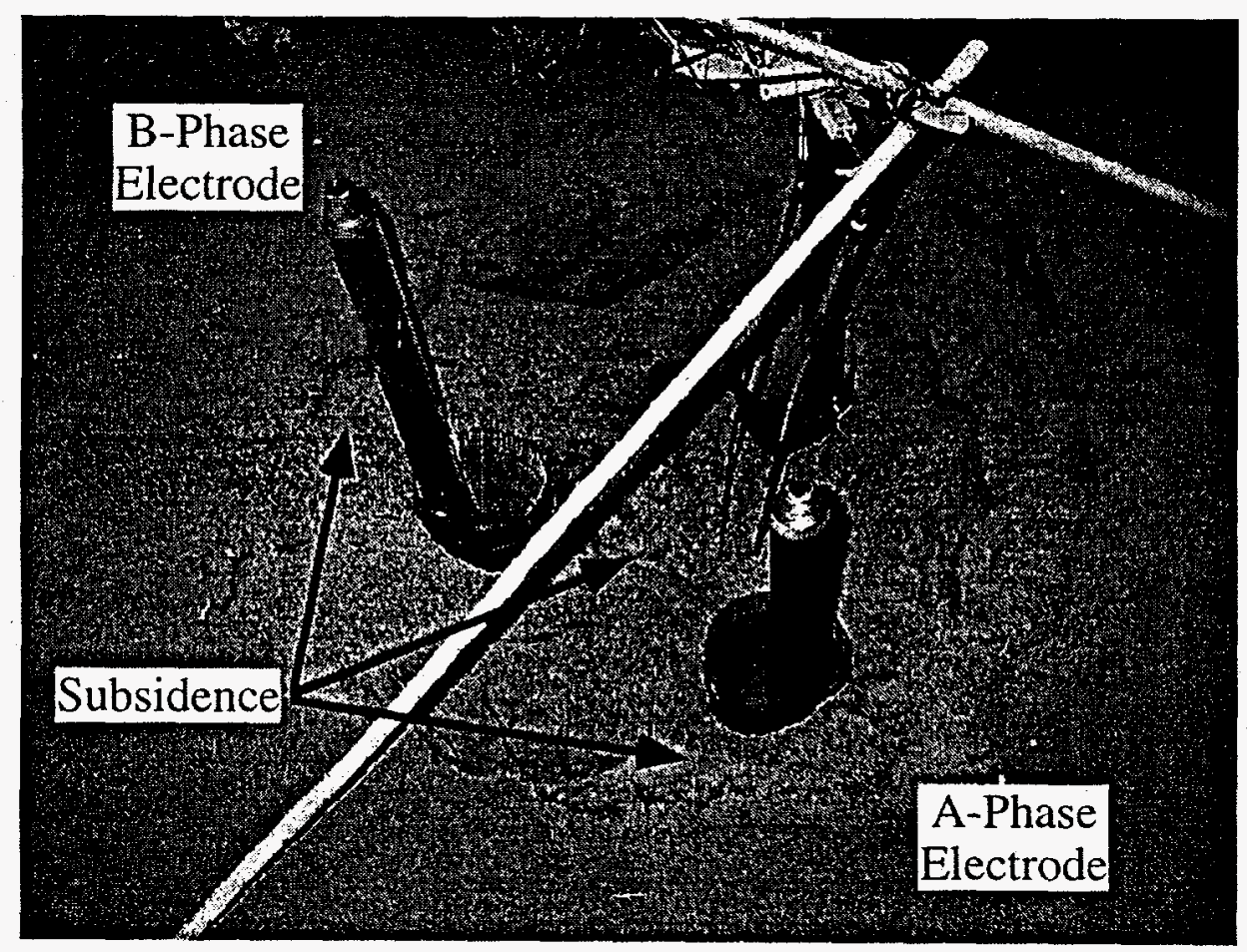

FIGURE 4.6. Observation of Subsidence at End of Engineering-Scale Test 


\subsection{TEMPERATURE PROFILES}

Thermocouple arrays were placed along the vertical axis to monitor melt-growth and temperature profiles both above and below the vitrification zone. Using engineering-scale tests initiated from the surface as a guide, a lateral array was placed at a $90-\mathrm{cm}$ depth to monitor the outward growth of the fully established melt. In addition, thermocouples along this array placed within the area encompassed by the electrodes provided an indication of the shape of the advancing bottom melt front. Figures 4.7 through 4.9 illustrate the temperature profiles for, respectively, the vertical array below the starter path, the vertical array above the starter path, and the lateral array.

The temperature profiles in Figures 4.7 and 4.9 are typical of those seen for melts initiated at the soil surface. Soil temperatures rose to a plateau of $100^{\circ} \mathrm{C}$ to boil-off soil moisture and then rapidly climbed to the soil's melting temperature. The lengthening time interval for evenly spaced points to reach a given temperature (say $1000^{\circ} \mathrm{C}$ ) is also characteristic of a melt initiated at the surface. Therefore, downward propagation of the melt is feasible in the soil subsurface and has the same characteristics as a surface-initiated melt.

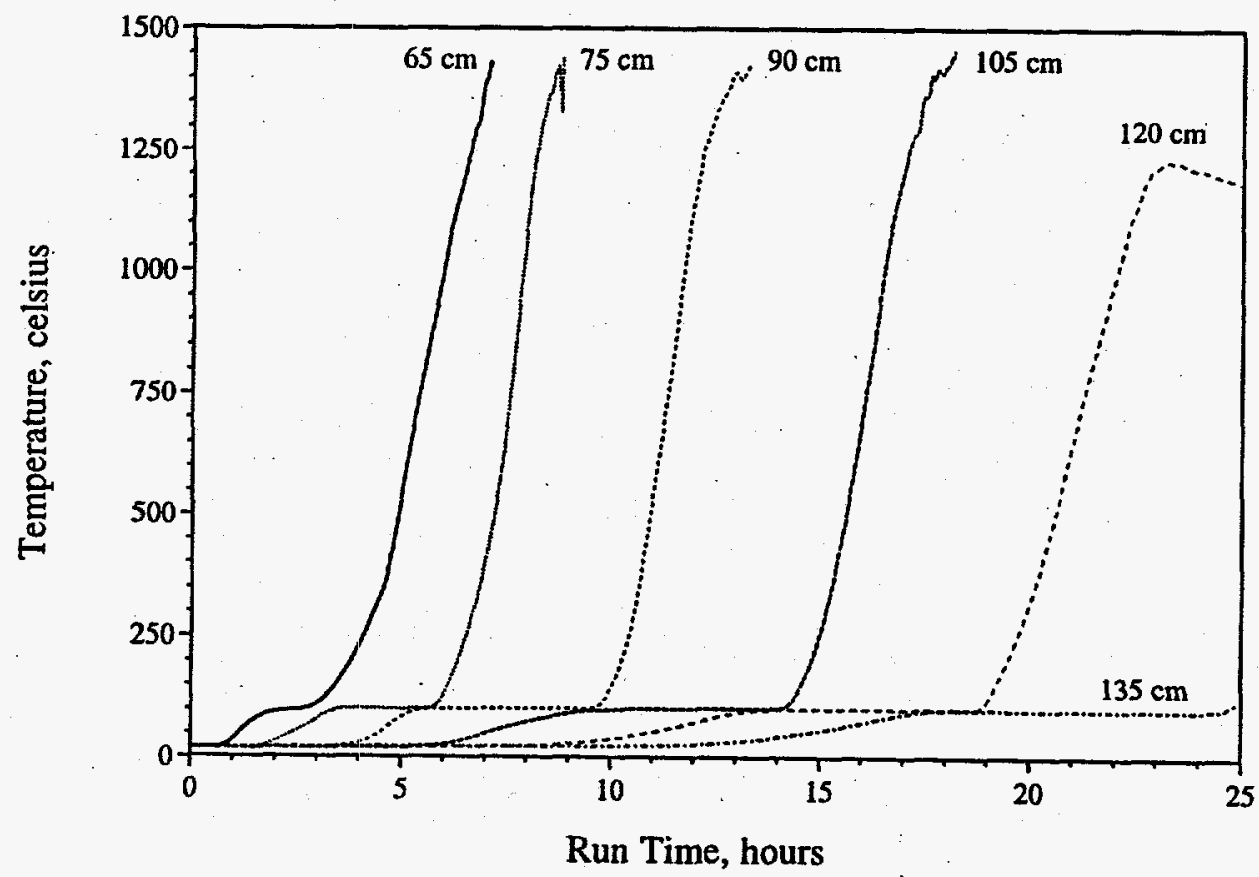

FIGURE 4.7. Temperature Profile of Vertical Thermocouple Array Below Vitrification Zone 


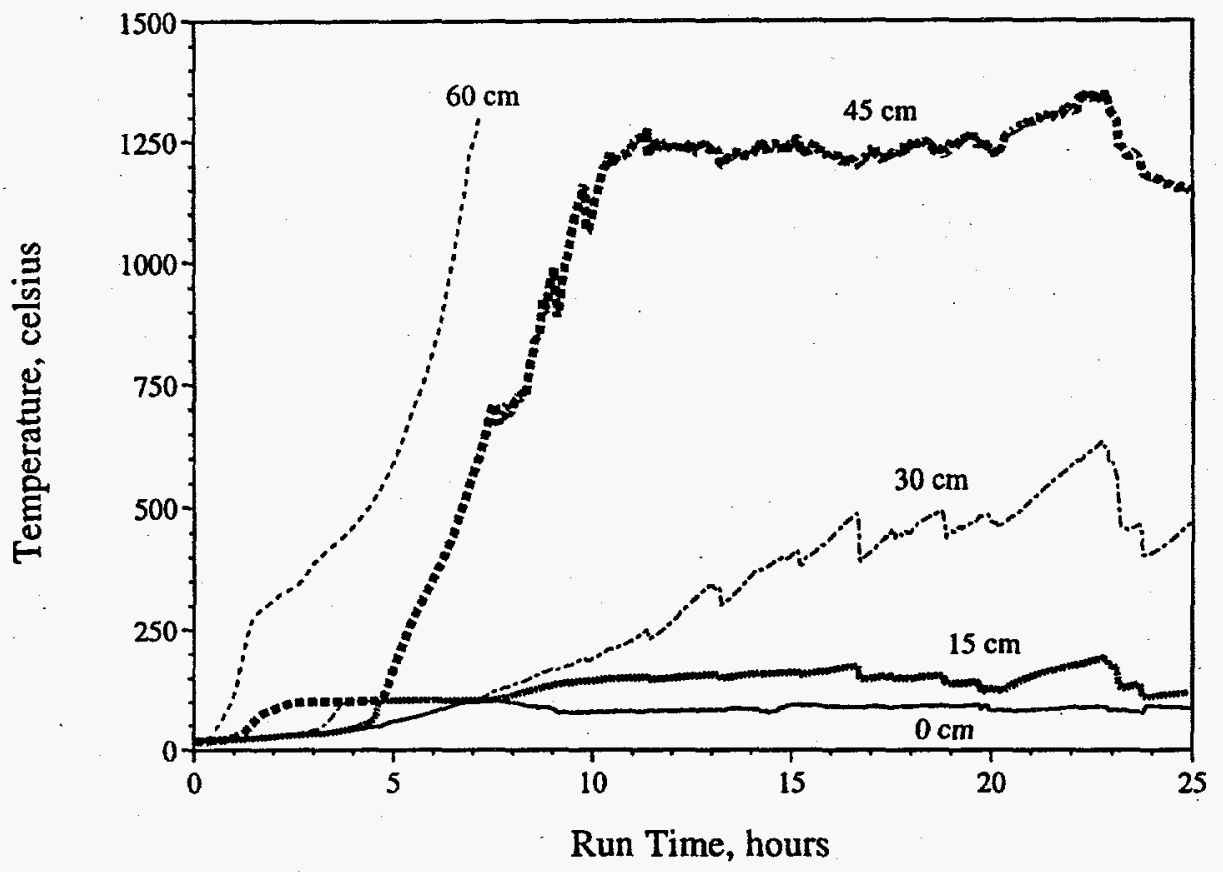

FIGURE 4.8. Temperature Profile of Vertical Thermocouple Array Above Vitrification Zone

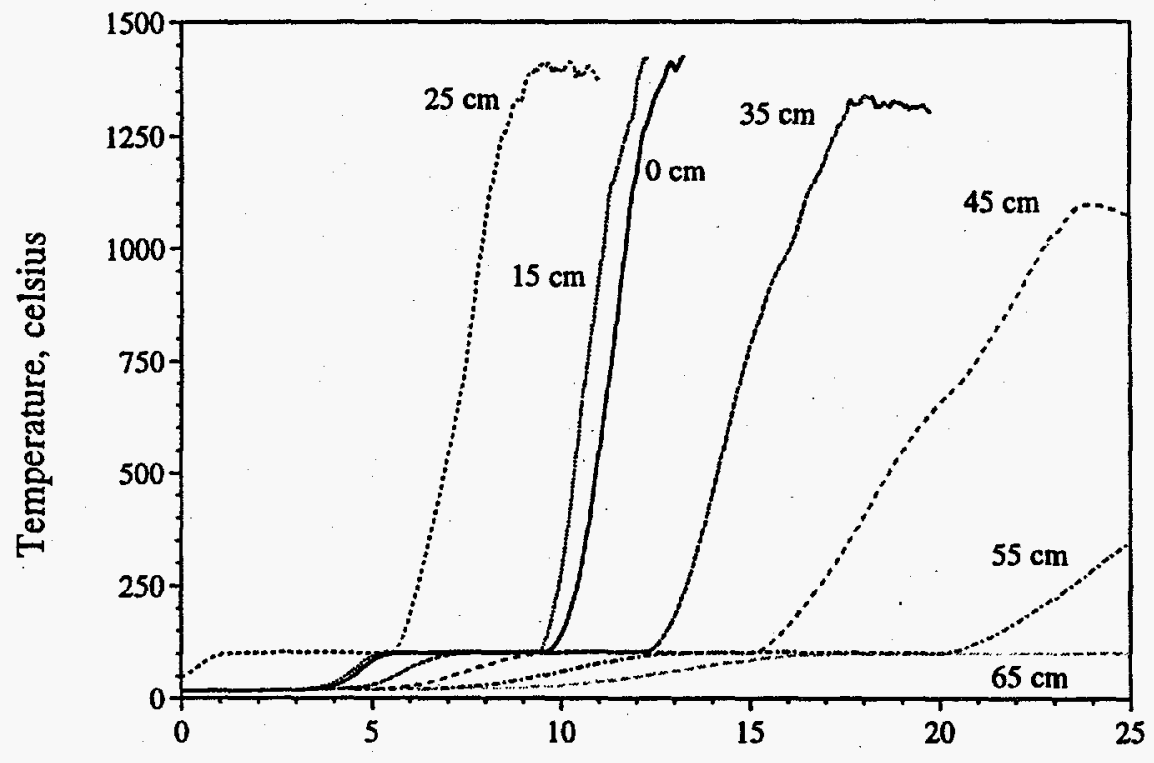

Run Time, hours

FIGURE 4.9. Temperature Profile of Lateral Thermocouple Array 
Comparison of the temperature profiles through hour 5 at $45-\mathrm{cm}$ and $30-\mathrm{cm}$ depths (Figure 4.8) with $75-\mathrm{cm}$ and $90-\mathrm{cm}$ depths (Figure 4.7) shows that, for points equidistant from the starter path $(60 \mathrm{~cm})$, upward heating predominated. This is as expected, since heat is not only conducted through the soil, but is transferred upward by gases (predominately steam) evolved during start-up. However, once the melt is fully established (after hour 5), the melts tended to propagate downward. The creation of a void space above the melt (the melt is denser than the soil) changes the dominant heat transfer mechanism from conduction to radiation. The creation of a void space is indirectly supported by the data in Figure 4.8 , which shows periodic, sudden drops in temperature that correlate with subsidence of cooler soil into hotter regions. This scenario is further supported by post-test examination of the block (see Section 4.4).

\subsection{PREDICTED MELT SHAPE}

Figure 4.10 shows the depth of the ISV melt front as indicated by the average depth of the electrodes and the point at which a centerline thermocouple reached $1200^{\circ} \mathrm{C}$. As shown in the figure, the melt front at the electrodes led the front at the centerline until hour 16. This indicates that for much of the test run, the bottom of the ISV melt was concave, either with legs like a stool or with a uniform brim like an upside down bowl. Data from the lateral thermocouple array suggests that the likely shape was an upside down bowl due to the following. From Figure 4.9, the thermocouple $25 \mathrm{~cm}$ from the centerline reached a temperature of $1350^{\circ} \mathrm{C}$ at hour 10 . At this time, the average electrode depth was $92 \mathrm{~cm}$, which is consistent with the postulated bowl shape since the $25-\mathrm{cm}$ lateral thermocouple is at a depth of $90 \mathrm{~cm}$.

The order in which the lateral thermocouples at the $90-\mathrm{cm}$ depth heated $(25 \mathrm{~cm}, 15 \mathrm{~cm}$, centerline, $35 \mathrm{~cm}, 45 \mathrm{~cm}, 55 \mathrm{~cm}$, and $65 \mathrm{~cm}$ ) further supports a melt shape in which the bottom of the vitrification is concave. The closeness in time at which the $15-\mathrm{cm}$ and centerline thermocouples reach $1350^{\circ} \mathrm{C}$ suggests that this region of the melt front is fairly flat. Therefore, the progression of the bottom of the vitrification zone went from a very deep bowl to fairly flat. Since the lateral thermocouple $35 \mathrm{~cm}$ from the centerline reached $1350^{\circ} \mathrm{C}$ near the end of the test (hour 18), the overall shape of the growing vitrification zone was believed to be a uniform cylinder with limited outward growth. The radius of the final block, based on data in Figure 4.9, was predicted to be 40 to $45 \mathrm{~cm}$. 


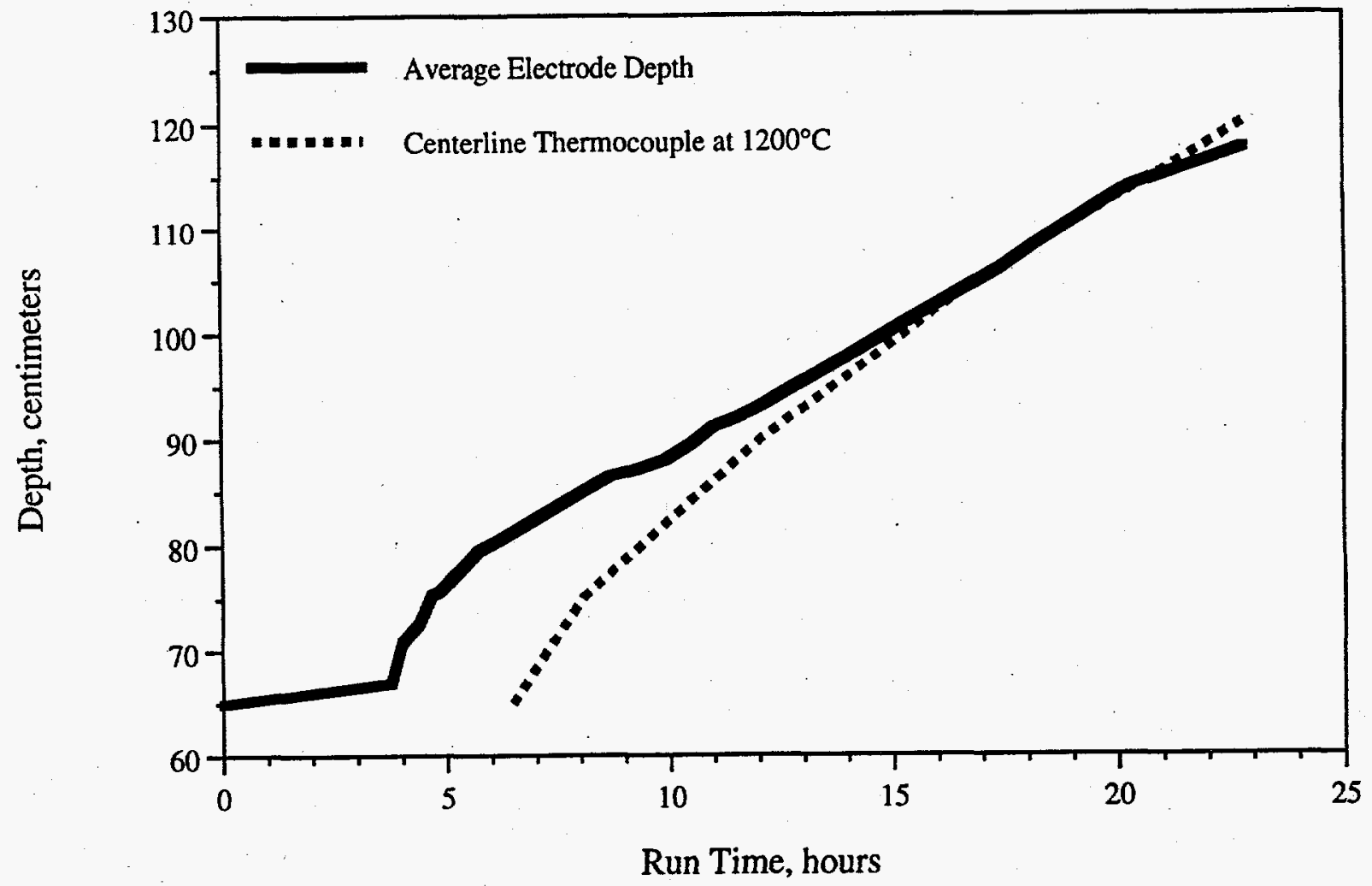

FIGURE 4.10. Melt Depth for Engineering-Scale Test

\subsection{FINAL ISV BLOCK}

Figure 4.11 shows the final ISV block with the region around the B-phase electrode exposed. Measurements from surface grade to the top of the melt indicated a depth of $60-\mathrm{cm}$ to the middle portion of the melt and an average depth of $45 \mathrm{~cm}$ to points along the rim. Measurement of the block circumference at various points results in a calculated average radius of $45 \mathrm{~cm}$, which was consistent with predictions based on the lateral thermocouple data. The average height of the block was $65 \mathrm{~cm}$, for an estimated block volume of $4.1 \times 10^{5} \mathrm{~cm}^{3}$. As shown in Figure 4.10, this block volume is composed of three distinct regions - a porous upper region, a solid core region, and sintered soil surrounding the entire block. The most notable feature absent from the final block is a significant void space. The absence of a void space supports the postulated mechanism for soil subsidence (see Section 4.2). 


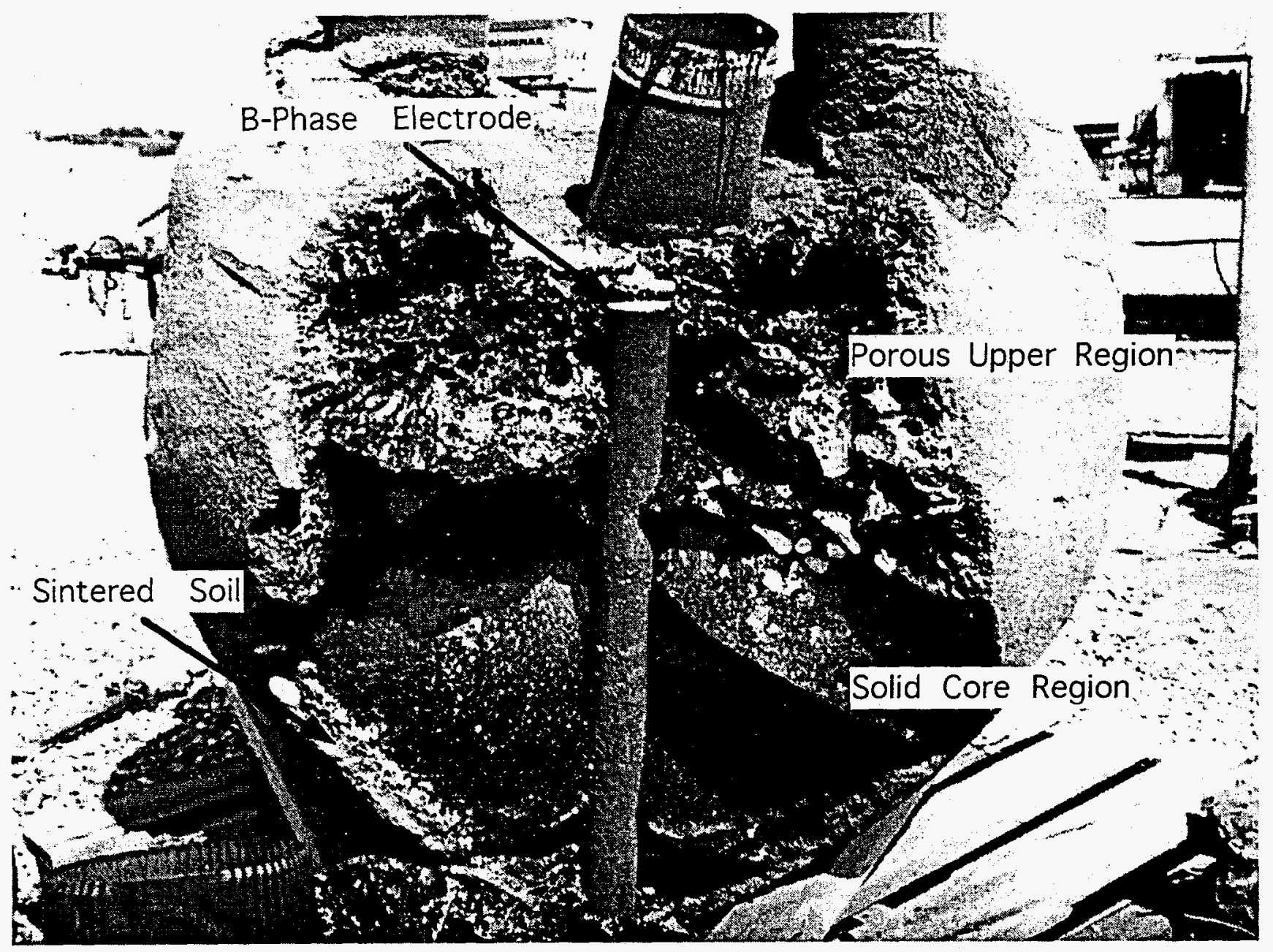

FIGURE 4.11. Final Engineering-Scale Block with B-Electrode Phase Exposed

The average thickness of the upper porous region is $15 \mathrm{~cm}$, as calculated from using the 5 -cm-diameter electrode in Figure 4.10 as a reference. A porous region is typically formed when gases escaping the vitrification zone either become trapped in the cooler, more viscous upper regions of a melt or create voids that do not collapse. Although the soil overburden would tend to insulate the upper regions of the melt and keep it hot, the presence of the porous region suggests it was still cooler than other areas of the melt. The average thickness of the sintered soil zone is about $2 \mathrm{~cm}$, thinnest at the top of the block $(<1 \mathrm{~cm})$ and fairly uniform everywhere else. The thickness of the sintered zone reflects the temperature gradient from the melt to the surrounding soil. Since the properties of the soil are considered constant, the thinner sintered zone at the top of the block supports the observation of the upper region being cooler than other areas of the melt. 


\subsection{REFERENCES}

Buelt, J. L., and L. E. Thompson. 1992. "The In Situ Vitrification Integrated Program: Focusing an Innovative Solution on Environmental Restoration Needs." In Spectrum '92 Proceedings of the International Topical Meeting on Nuclear and Hazardous Waste Management, Vol. 1, pp. 322-326. August 23-27, 1992, Boise, Idaho.

Luey, J., and D. K. Seiler. 1994. Evaluation of New Starter Path Geometries for In Situ Vitrification. PNL-10122, Pacific Northwest Laboratory, Richland, Washington.

Luey, J., T. D. Powell, W. O. Heath, and R. L. Richardson. 1992. Evaluation of New Concepts for In Situ Vitrification: Power System, Melt Insulation, and Off-Gas Containment. PNL-8231. Pacific Northwest Laboratory, Richland, Washington.

Tixier, J. S., J. A. Stottlemyre, and M. T. Murphy. 1991. "Vitrified Underground Barriers." In Waste Management '91 Vol 1, ed. R. G. Post, pp. 603-611. February 24-28, 1991, Tucson, Arizona. 
APPENDIX A

1992 ISV BENCH-SCALE TEST: OVERVIEW 


\section{APPENDIX A}

\section{ISV BENCH-SCALE TEST: OVERVIEW}

\section{INTRODUCTION AND OBJECTIVES}

In October 1992 a proof-of-principle bench-scale test was performed to demonstrate the ability to initiate the ISV process at depth and proceed upward. Applying ISV in this manner was recognized as a technique for substantially increasing ISV depth capabilities. Testing involved the use of uncontaminated Hanford soil consisting mainly of fine- to medium-grained sands. The test was performed in PNL's engineering-scale unit.

The overall objective of the bench-scale test was to demonstrate the proof-of-principle concept of promoting underground start up and sustaining upward melt growth. Technical issues identified for this application included soil densification/subsidence and venting of water vapor from the soil. These technical issues were identified as having the potential to affect the heat transfer rate above the vitrification zone, and thus, the ability to process upwards. Specific objectives of the test are as follows:

- Determine the upward processing melt rate. Downward processing rates for ISV melts initiated at the surface have been established for various soil types, waste configurations, and ISV test scales; however, no data has been established for upward melt growth.

- Obtain performance data on a method to mitigate the potential effects on the subsurface vitrification process due to soil densification. A method for adding soil to the subsurface melt was tested and evaluated.

\section{DESIGN OF SOIL ADDITION SYSTEM}

Vitrification of soil results in a volume reduction of approximately $30-40 \%$ due to the densification of the vitrified product relative to normal soil. For sites involving buried waste, volume reductions of $70 \%$ have been observed due to the greater void space in the waste region (Callow et al. 1991). A standard ISV melt initiated at the soil surface is not affected by the soil subsidence associated with the volume reduction; however, for a melt initiated in the subsurface, subsidence (or the lack of it) was postulated to have an influence on the process.

The postulated scenario of concern was the creation of a void space above the vitrification zone. This void would effect the upward growth rate by changing the dominant heat transfer 
mechanism from conduction through the soil to radiation across the void. Pre-test calculations showed that radiant heat transfer across the developing void space would be sufficient to propagate the melt upwards. However, a soils addition system was designed as a contingency if 1) the assumptions for the calculations were incorrect or 2) the melt rate was less than $2.5 \mathrm{~cm} / \mathrm{hr}$ (typical downward melt rate).

The soils addition system consisted of a borosilicate glass (Pyrex ${ }^{\circledR}$ ) pipe extending from inside the off-gas hood to a point in the soil subsurface. An angular tee was used so that fill soil could be added through the angle section while minimizing effects on venting gases in the straight section. In addition, the straight section was designed to allow for the use of a rod to clear any obstructions that might form at the bottom of the pipe. Adding fill soil, combined with rasing the electrodes, would increase the upward melt rate by 1) creating a situation for conductive heat transfer (soil in contact with molten soil) and 2) moving the melt's hot spot closer to its upper surface (current flow between electrodes only in upper region).

\section{TEST CONFIGURATION}

Figure A.1 illustrates the bench-scale test configuration. The soil addition pipe was $5-\mathrm{cm}$ in dia. and centered between the two 5-cm dia. graphite electrodes. Soil was added by terminating power to the system, removing the viewing window on the off-gas hood and then adding a section of pipe for soil addition. Electrode spacing was $24.1 \mathrm{~cm}$ with an insertion depth of $132 \mathrm{~cm}$. A starter path was placed at a depth of approximately $120 \mathrm{~cm}$ to initiate the ISV process. To ensure electrical contact between the electrode and starter path, a conductive spring was wrapped around the electrode at the point of contact with the starter path. Figure A.2 provides greater detail on the configuration of the starter path and illustrates the location of some of the thermocouples used to monitor the temperature profile and melt front location along the vertical axis (the depth of each thermocouple from grade is shown).

Power was supplied by a single phase, $10 \mathrm{kVA}$ transformer. The target power level for the bench-scale test was $10 \mathrm{~kW}$, which is standard for this ISV test scale. Electrical data was recorded every 2 minutes using a Fluke multimeter linked to an IBM computer. The computer display was updated every 6 seconds to facilitate responsive operator control. 


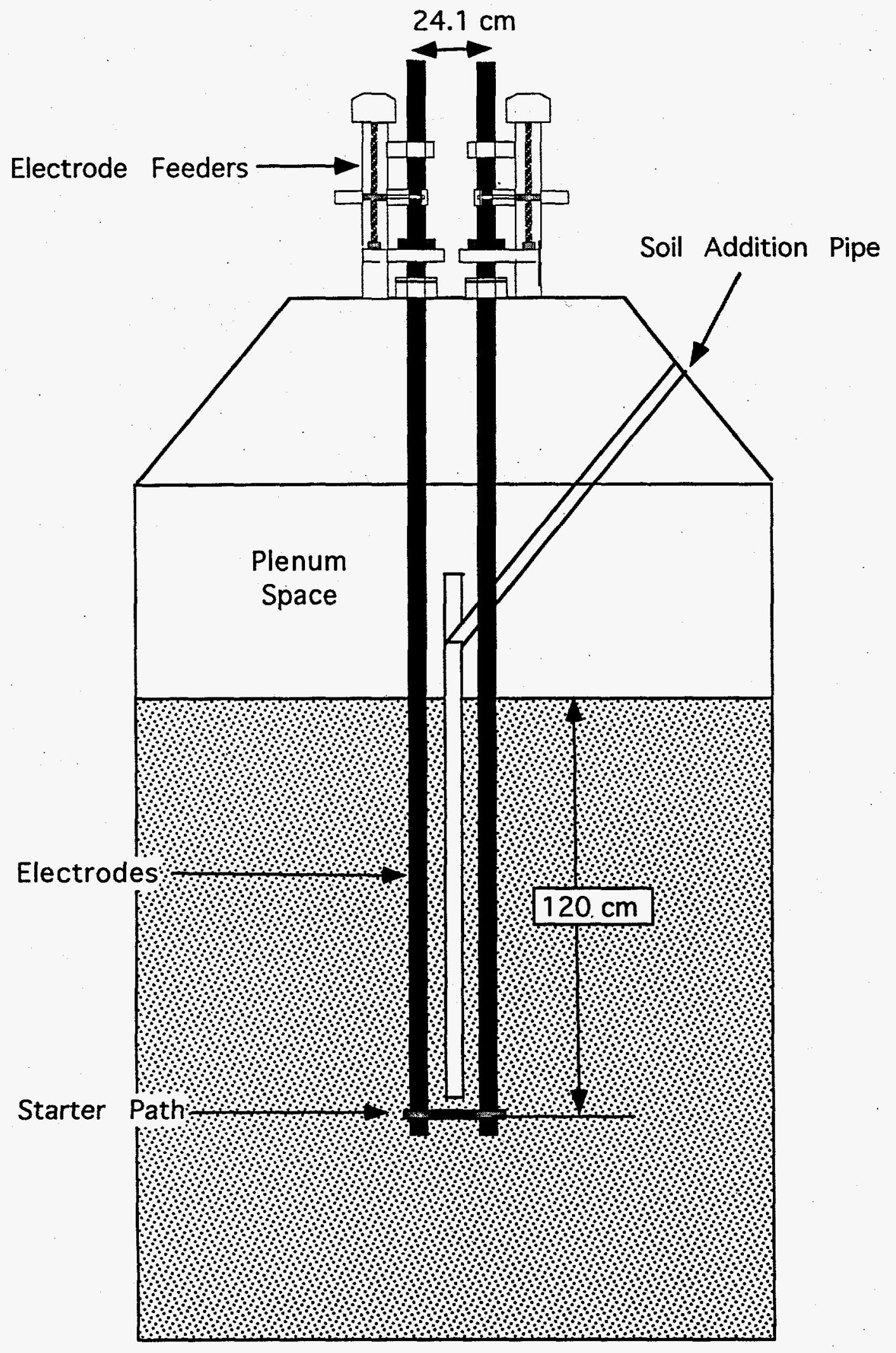

FIGURE A.1. Test Configuration for 1992 Bench-Scale Test 


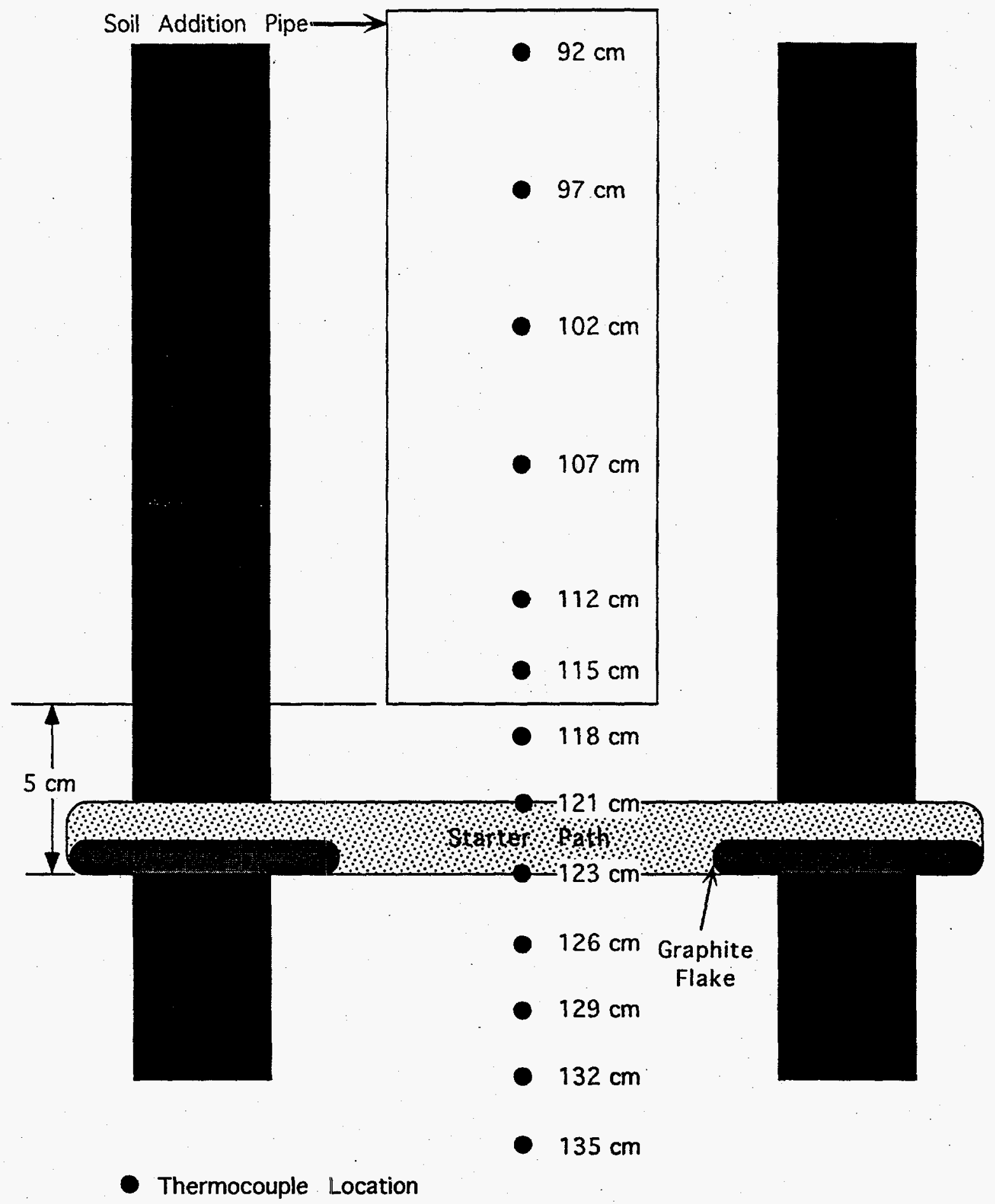

FIGURE A.2. Location of Selected Thermocouples for 1992 Bench-Scale Test 


\section{RESULTS AND DISCUSSION}

Powered operation for this test totaled 49 hours. The resulting ISV block weighed approximately $325 \mathrm{~kg}$ and had an oval cross-section, viewed in elevation. Figure A.3 illustrates two views of the final block after it was exposed along the plane of the electrodes. The major diameter was about $60 \mathrm{~cm}$ while the minor diameter of the oval was approximately $48 \mathrm{~cm}$. Total height of the excavated monolith was an average of $80 \mathrm{~cm}$; however, the actual height of the vitrified portion was only $55 \mathrm{~cm}$ due to a void space within the excavated monolith (shown in the right photo in Figure A.3). During excavation of the block it was noted that the top of the block was $45 \mathrm{~cm}$ below surface grade. This places the bottom of the block at a depth of $125 \mathrm{~cm}$.

Using the total height of the block as an indication of the amount of material processed gives an average upwards melt rate of about $1.6 \mathrm{~cm} / \mathrm{hr}$ ( $80 \mathrm{~cm}$ processed in 49 hours). This melt

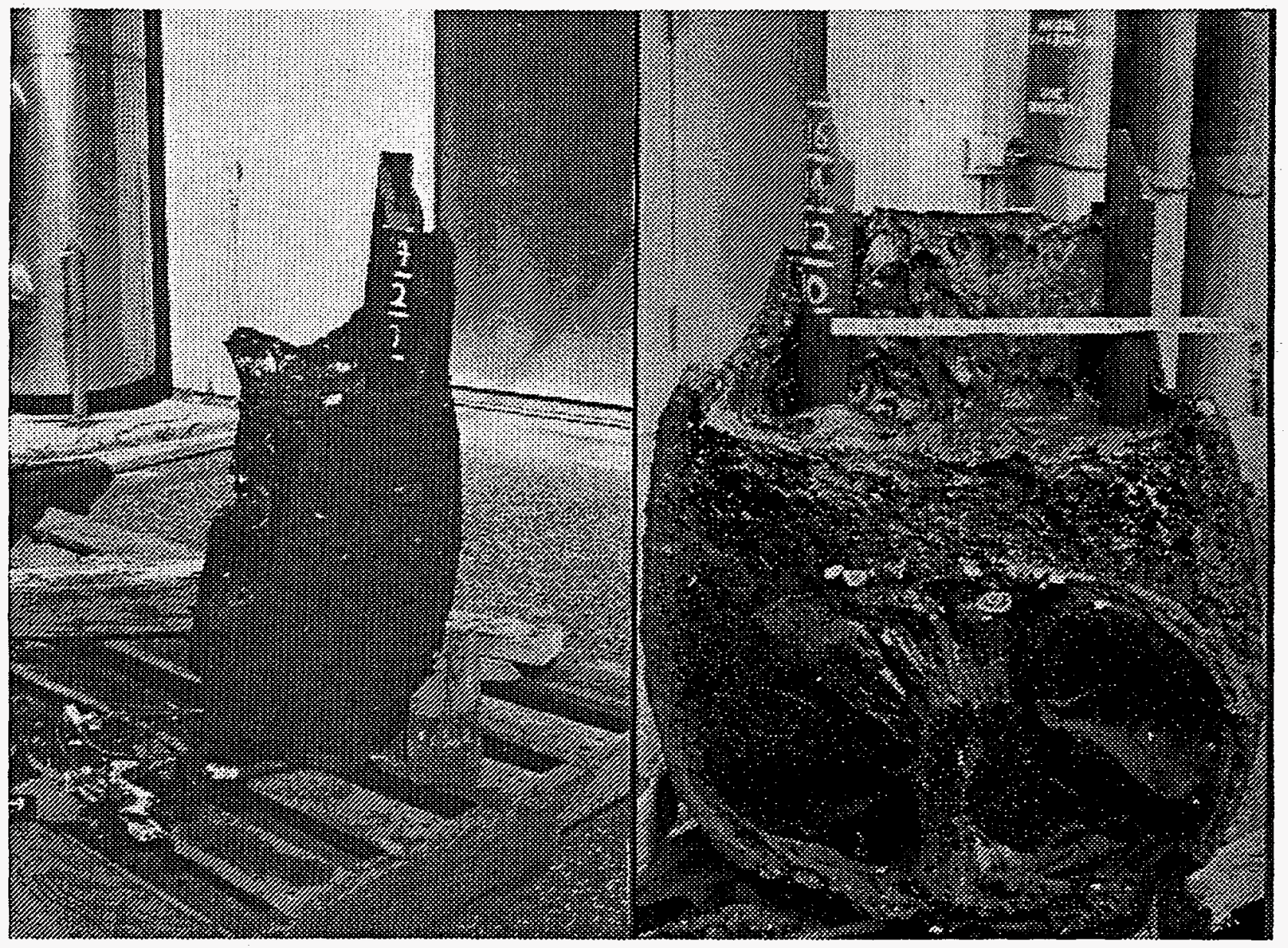

FIGURE A.3. Side and Front Views of ISV Block Exposed Along Electrode Plane 
rate is significantly less than the average $2.5 \mathrm{~cm} / \mathrm{hr}$ downward melt rate. As discussed previously, the likely cause for this decreased melt rate is the change in the dominant heat transfer mechanism due to the presence of the void space. A review of the laboratory record book shows that the soil addition system became clogged about 8 hours into the test and did not allow material to be added to the void; however, observations during the test showed periodic subsidence from the surface. This subsidence indicates that soil above the vitrification zone was able to periodically penetrate the upper sintered zone and flow into the void space. Soil was added to the surface throughout the test to compensate for the subsidence.

The soil addition method tested did not aid in the prevention of a void space being formed above the ISV melt. The primary cause for the failure of the system was clogging of the pipe, either due to the addition of soil or from melting of the pipe end by the advancing thermal front. A method for the addition of material is still considered necessary for this ISV application so as to minimize the effects from subsidence. One effect attributed in part to subsidence is fluctuation in the current and voltage input. Figure A.4 illustrates the current and voltage profiles for the test. Much of the fluctuation seen in Figure A.4 is attributable to subsidence events that change the

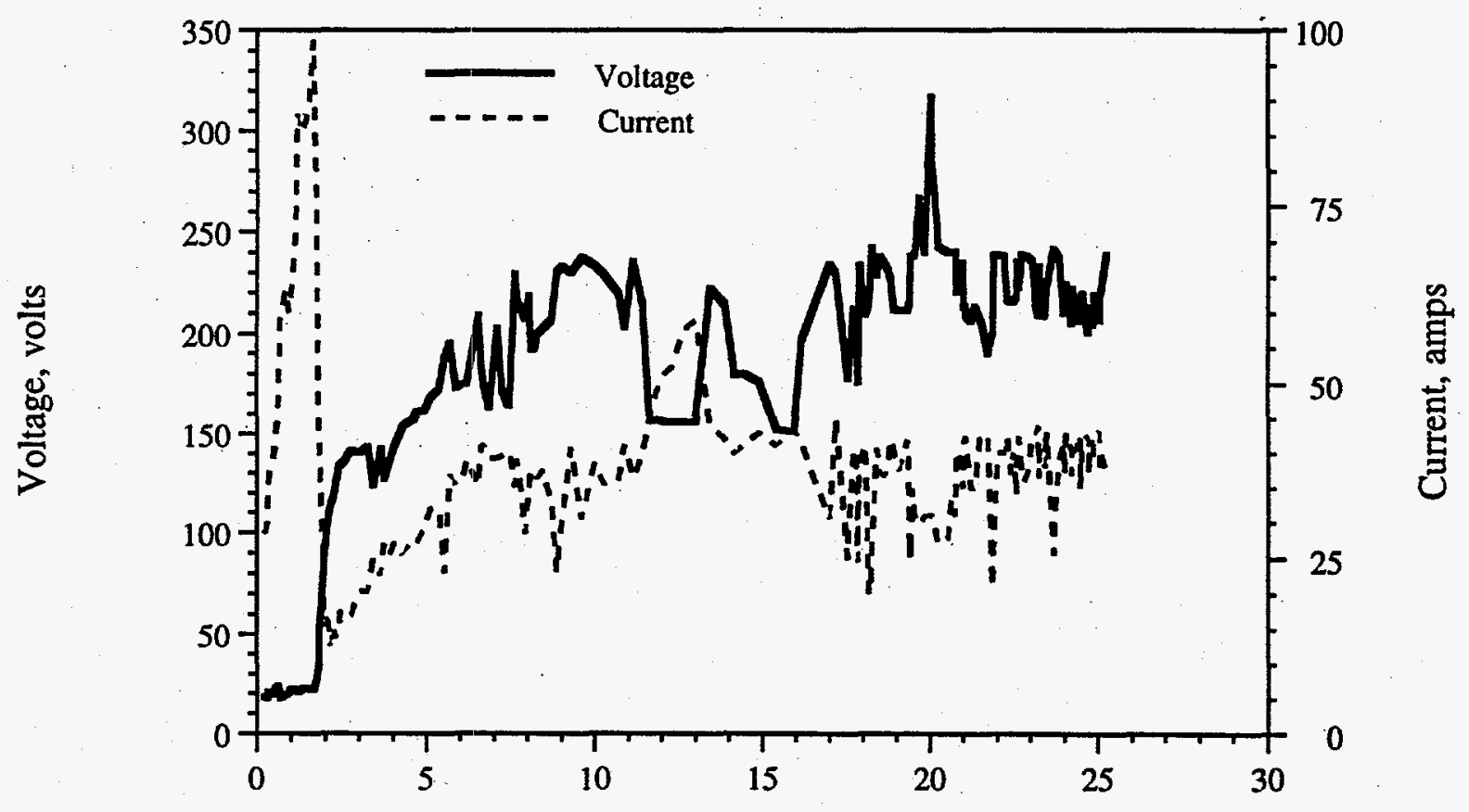

Run Time, hours

FIGURE A.4. Current and Voltage Profile for 1992 Bench-Scale Test 
electrical resistance between the electrodes. Another cause for the fluctuations is the method of retracting the electrodes to propagate the melt upwards. This method changes the electrical resistance between the electrodes by changing the electrode surface area in contact with the molten soil.

Figures A.5 and A.6 illustrate, respectively, the temperature profiles at locations above and below the initiation depth. The temperature profiles below the ISV melt in Figure A.6 are typical of a melt initiated at the surface. Profiles for thermocouples immediately above the start-up depth (through $115-\mathrm{cm}$ depth) are also typical for the ISV process. The remaining temperature profiles above the start-up depth have characteristics similar to the typical ISV process (temperature plateau at $100^{\circ} \mathrm{C}$ ) but show periodic temperature drops. These temperature drops are caused by subsidence events whereby cooler soil from above the thermocouple moves down to the thermocouple location.

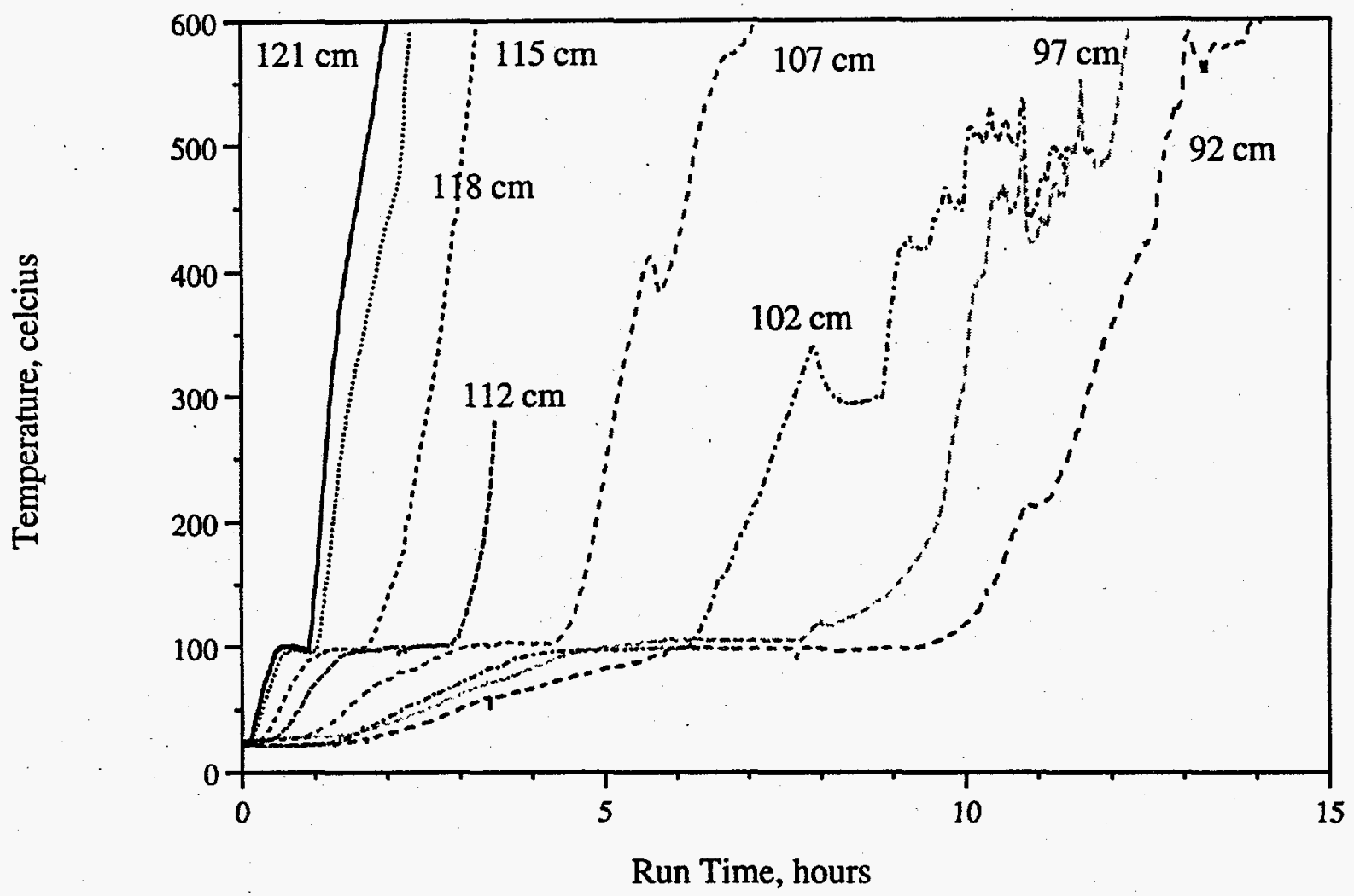

FIGURE A.5. Selected Temperature Profiles from Thermocouples Above Start-Up Depth 


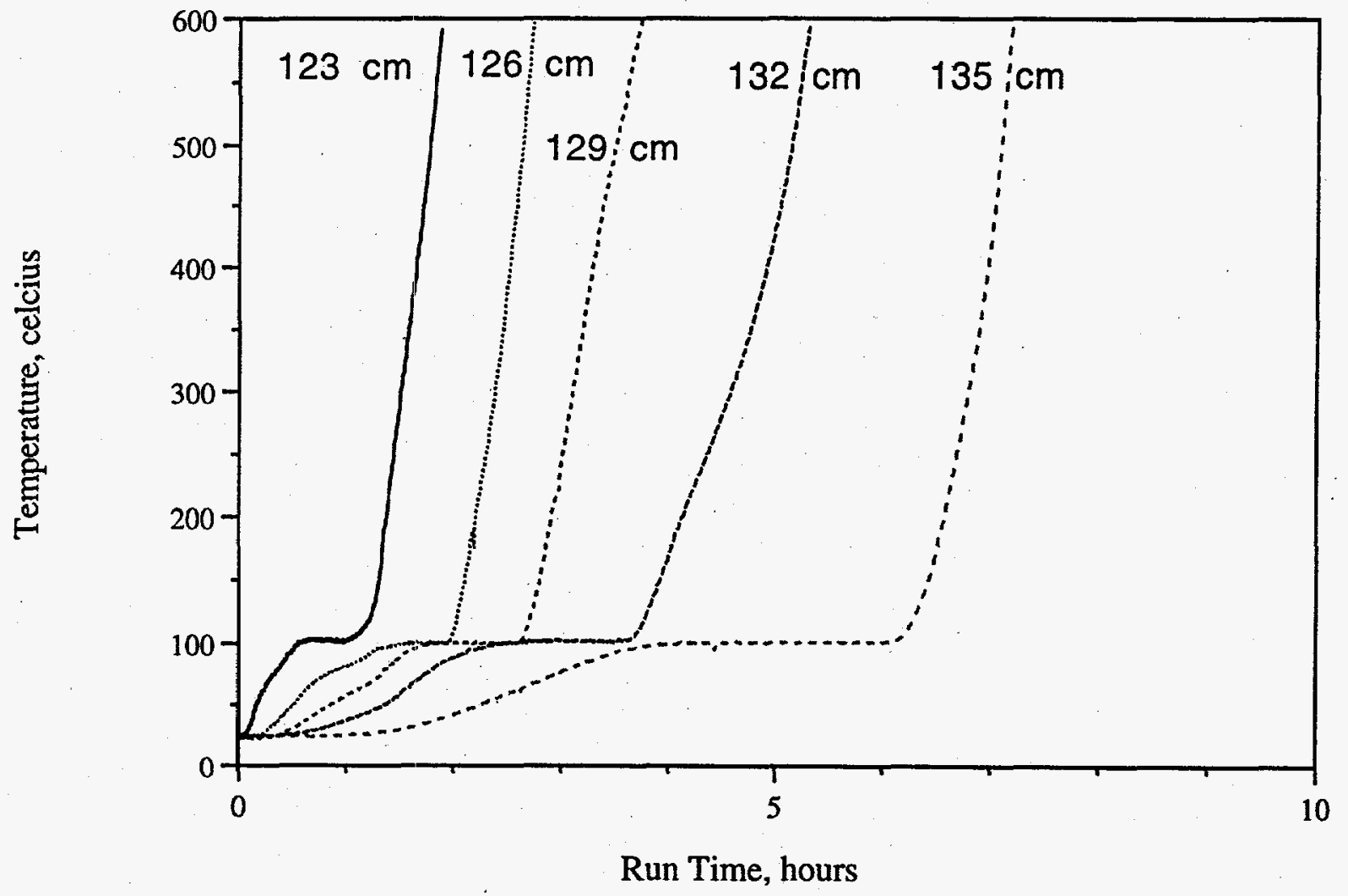

FIGURE A.6. Selected Temperature Profiles from Thermocouples Below Start-Up Depth 


\section{REFERENCES}

Callow, R. A., L. E. Thompson, J. R. Weidner, C. A. Loehr, B. P. McGrail, and S. O. Bates. 1991. In Situ Vitrification Application to Buried Waste: Final Report of Intermediate Field Tests at Idaho National Engineering Laboratory. EGG-WTD-9807, EG\&G Idaho, Inc., Idaho Falls, Idaho. 